
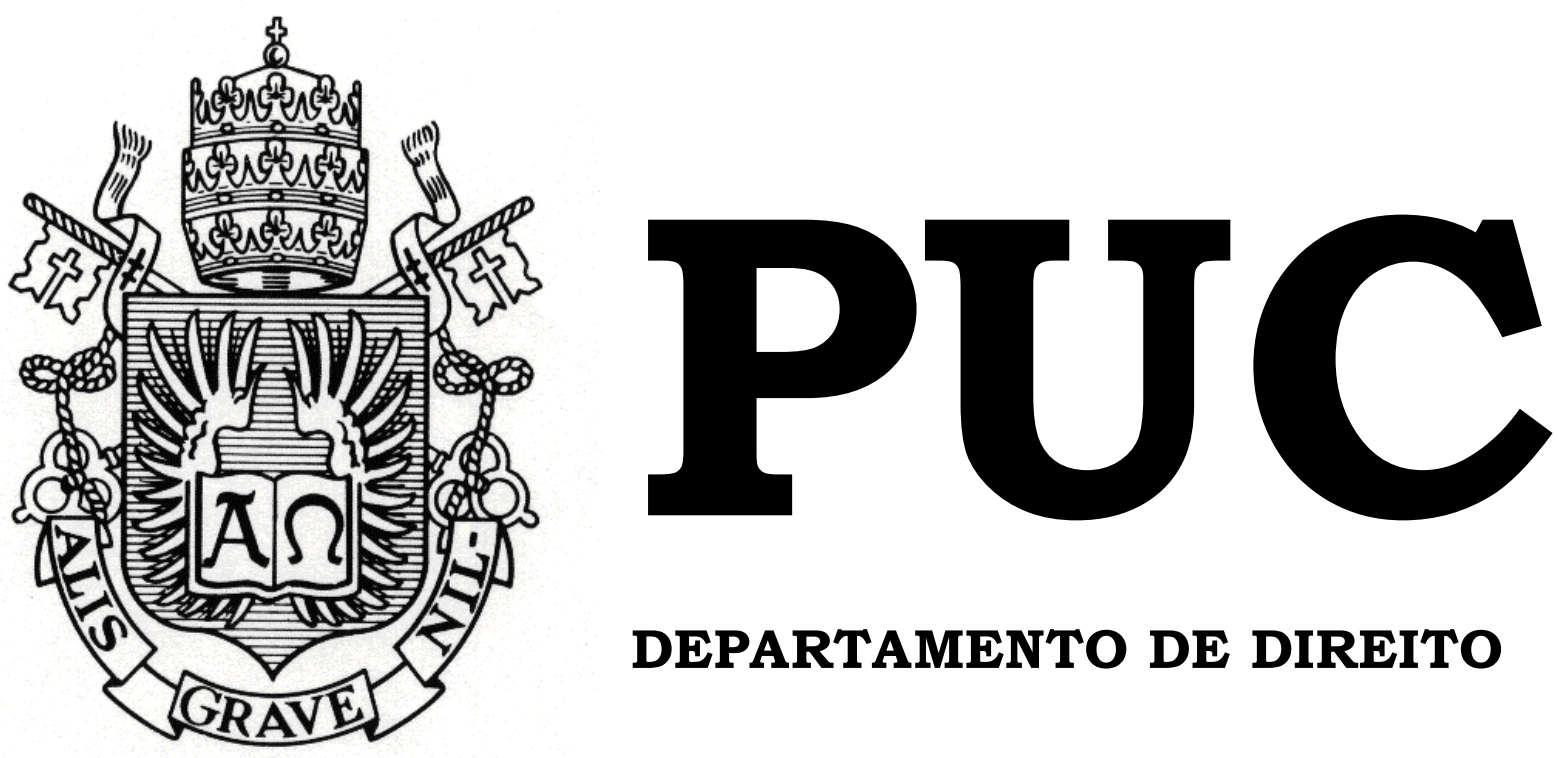

DEPARTAMENTO DE DIREITO

\title{
MEDIDAS DEFENSIVAS À TOMADA HOSTIL DE CONTROLE EM SOCIEDADES ANÔNIMAS: UMA ANÁLISE COMPARATIVA ENTRE $O$ DIREITO BRASILEIRO E O DIREITO ESTRANGEIRO
} Por GABRIEL BANWELL AYRES

ORIENTADORA: Norma Jonssen Parente 2016.1

PONTIFÍCIA UNIVERSIDADE CATÓLICA DO RIO DE JANEIRO RUA MARQUÊS DE SÃO VICENTE, 225 - CEP 22451-900 RIO DE JANEIRO - BRASIL 


\title{
MEDIDAS DEFENSIVAS À TOMADA HOSTIL DE CONTROLE EM SOCIEDADES ANÔNIMAS: UMA ANÁLISE COMPARATIVA ENTRE O DIREITO BRASILEIRO E O DIREITO ESTRANGEIRO
}

por

GABRIEL BANWELL AYRES

\begin{abstract}
Monografia apresentada ao
Departamento de Direito da Pontifícia Universidade Católica do Rio de Janeiro (PUC-Rio) para a obtenção do Título de Bacharel em Direito.
\end{abstract}

Orientador: Norma Jonssen Parente 2016. 1 


\section{AGRADECIMENTOS}

Meus primeiros e mais singelos agradecimentos vão aos meus pais, Paulo e Rose, que com amor, afeto, sabedoria e apoio incondicional em tudo que faço, me ensinaram tudo que sei. Mesmo morando longe, impossível não sentir a presença deles em cada etapa do meu dia.

Aos meus irmãos Thomas e Felipe. Thomas, fonte de grande inspiração e inestimável conhecimento e Felipe, fiel companheiro, amigo e detentor de um futuro brilhante na carreira jurídica.

À minha namorada, Mariana, que pacientemente me apoiou neste tempo dedicado à esta monografia, sempre com seu sorriso diário.

Aos meus amigos que se juntaram à carreira jurídica, em especial aos queridos Rodolfo e Leonardo, que me acompanham desde o primeiro dia no pilotis até este momento.

Aos meus professores, que com toda a dedicação do mundo puderam dispor um pouco dos seus tempos para se dedicar ao magistério e agraciar minha vida com seus conhecimentos.

Sem vocês, nada disso seria possível! 
"If I have seen further, it is by standing on the shoulders of giants." - Sir Isaac Newton 


\section{RESUMO}

O presente trabalho tem como objetivo fazer uma análise comparativa entre os diferentes mecanismos para a defesa de tomadas de controle em sociedades anônimas, fazendo uma comparação entre o direito brasileiro e o direito norte-americano.

Para melhor entendimento de como cada medida pode ser usada e para melhor visualização do cenário entre os dois países, o presente trabalho também fará uma breve explicação dos diferentes tipos de poder de controle de companhias no Brasil.

As diferenças entre as medidas defensivas serão analisadas pelas diferentes esferas, analisando as diferenças econômicas, legais e históricas.

Palavras-Chave: Direito Societário. Direito Comparado. Tomada de Controle. Dispersão Acionária. Poder de Controle. Mecanismos de Defesa. 


\section{ABREVIAÇÕES}

BM\&FBovespa

CVM

IBGC

Novo Mercado

Nível 2

SEC
Bolsa de Valores, Mercadorias e Futuros de São Paulo (BM\&FBOVESPA S.A.

Comissão de Valores Mobiliários

Instituto Brasileiro de Governança Corporativa IBGC

Segmento de listagem de companhias da BM\&FBovespa com a mais alto grau de governança corporativa.

Segmento de listagem de companhias da BM\&FBovespa com alto grau de governança corporativa.

Securities and Exchange Comission 


\section{SUMÁRIO}

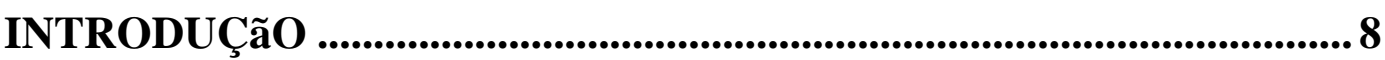

CAPÍTULO 1 - CONSIDERAÇÕES SOBRE O PODER DE CONTROLE E DISPERSÃO ACIONÁRIA ............................................14 CAPÍTULO 2 - PODER DE CONTROLE E AS SUAS PRINCIPAIS FORMAS CONTEMPORÂNEAS................................................................. 17

2.1. PODER DE CONTROLE EXTERNO ............................................ 17

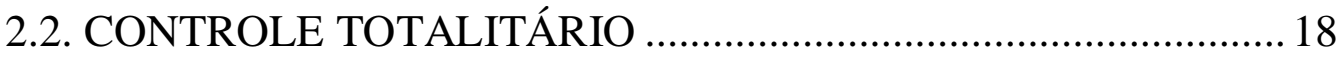

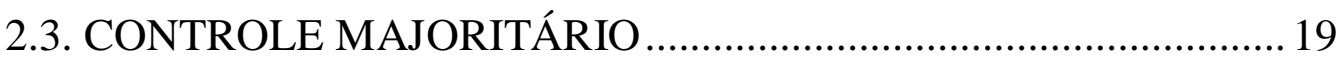

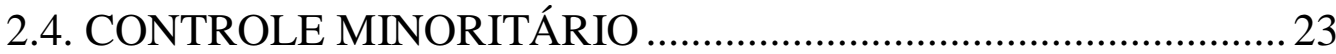

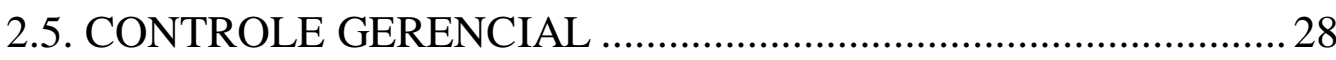

CAPÍTULO 3 - CONSIDERAÇÕES SOBRE A AQUISIÇÃO E A TOMADA DE PODER DE CONTROLE...............................................32

3.1. ESPÉCIES DE MECANISMOS DE PROTEÇÃO À TOMADA DE

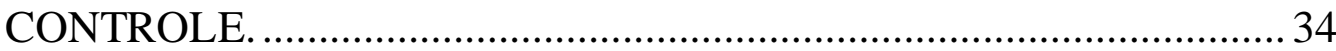

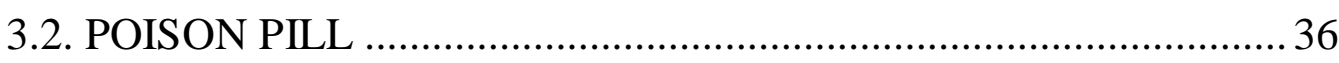

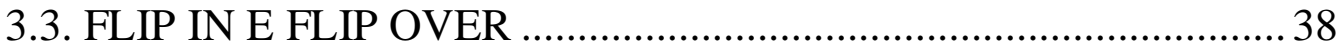

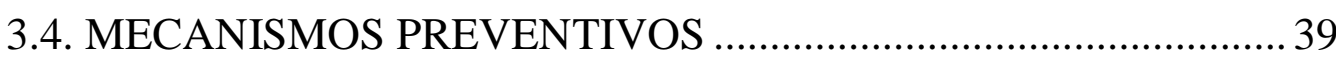

3.4.1. STAGGERED BOARD - CONSELHO DE ADMINISTRAÇÃO

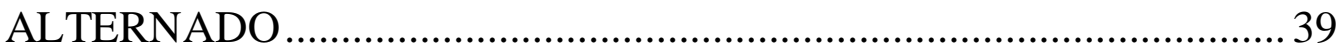

3.4.2. GOLDEN PARACHUTE - PARAQUEDAS DOURADO ........... 41

3.4.3. SUPERMAJORITY VOTES - QUÓRUM QUALIFICADO ........ 43

3.4.4. ACCELERATED LOANS - EMPRÉSTIMOS ACELERADOS 44

3.5. MECANISMOS REPRESSIVOS …………………….................... 45

3.5.1. WHITE KNIGHT - CAVALEIRO BRANCO ………………….... 45

3.5.2. WHITE SQUIRE - ESCUDEIRO BRANCO ................................ 46

3.5.3. CROWN JEWEL - JOIA DA COROA ……………..................... 48

3.5.4. GREENMAIL -CHANTAGEM SOCIETÁRIA ……………….... 49

3.5.5. PAC MAN DEFENSE- CONTRA ATAQUE ............................... 51 
3.6. OPA POR AQUISIÇÃO RELEVANTE DE PARTICIPAÇÃO - AS

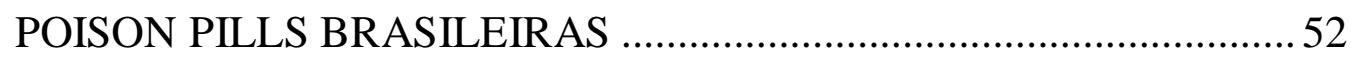

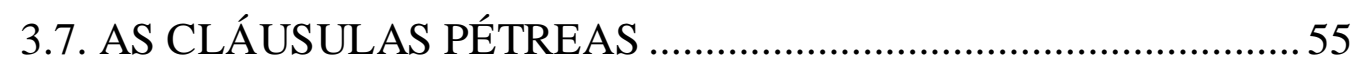

Capítulo 4 - COMPARAÇÕES E EXPERIÊNCIAS INTERNACIONAIS............................................................................58

4.1. BUSINESS JUDGMENT RULE - REGRA DO JULGAMENTO

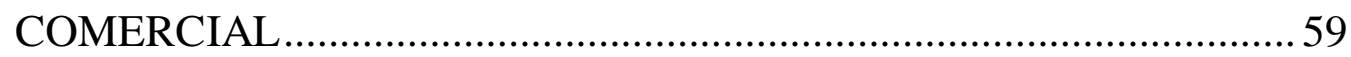

4.2. POSIÇÃO DO JUDICIÁRIO NORTE AMERICANO COM RELAÇÃO AO POISON PILL E DEMAIS MECANISMOS DE

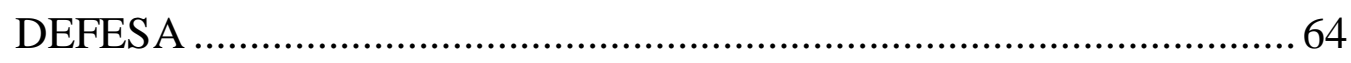

4.3. ANÁLISE COMPARATIVA ENTRE O DIREITO ESTRANGEIRO E O DIREITO BRASILEIRO COM RELAÇÃO ÀS MEDIDAS DEFENSIVAS DE TOMADA DE CONTROLE ……………………...... 66

CONCLUSÃO.................................................................................................... 68

REFERÊNCIAS BIBLIOGRÁFICAS .................................................. 72 


\section{INTRODUÇÃO}

A evolução das sociedades anônimas, e das sociedades empresárias em geral no Brasil, foi engatinhando em passos lentos até o começo século do dezenove. A primeira fase das sociedades empresárias no Brasil reinou durante todo o período colonial, em que a economia brasileira, ainda sobre o domínio da Coroa Portuguesa, era baseada puramente no extrativismo e na exportação à Europa.

Neste período a criação de sociedades empresárias era de cunho estratégico para a Coroa Portuguesa e, por isso, só podiam ser criadas mediante leis especiais designadas pelo legislador da Coroa Portuguesa no Brasil.

Nesta fase, denominada por Pontes de Miranda como fase do privilégio $^{1}$, as sociedades empresárias eram criadas através de decretos e alvarás que estabeleciam o objeto e principais características das sociedades, de forma semelhante a como empresas públicas e sociedades de economia mista são criadas atualmente.

Com a chegada da família real portuguesa no Brasil em 1808, o comércio, com as exportações aumentando devido às aberturas dos portos, começou a ser difundido em grande escala e a constituição de sociedades anônimas precisou passar por mudanças pelo legislador à época.

A fase do privilégio durou então até 1849 quando o Decreto n. 575 de 10 de janeiro de $1849^{2}$ foi promulgado e se iniciou o começo da era das autorizações para a constituição de sociedades anônimas.

\footnotetext{
${ }^{1}$ PONTES DE MIRANDA, Francisco Cavalcanti. Tratado de direito privado. t. L. Atualizado. São Paulo: Revista dos Tribunais, 2012, p. 60.

${ }^{2}$ Art. $1^{\circ}$ Nenhuma Sociedade anonyma poderá ser incorporada sem autorisação do Governo, e sem que seja por elle approvado o Contracto, que a constituir.
} 
Neste momento era necessário a autorização do Estado para um empresário ou grupo de sócios para se constituir uma sociedade anônima, dando grande poder ao Império para intervir na criação de sociedades anônimas.

O Código Comercial promulgado em 25 de junho de 1850, após tramitar no Congresso Nacional por mais de 15 anos, serviu como marco regulamentar de inúmeros tipos de sociedades empresariais.

O legislador a época se inspirou nos Códigos de Comércio da Espanha e Portugal e não designou lei especial para regular as sociedades anônimas, lembrando que o cenário da época era contextualmente completamente diferente ao cenário atual. As sociedades continuavam sendo ainda, via de regra, familiares, designadas a cumprir somente um objeto social de especialidade de uma família ou de um seleto grupo de sócios.

O Código Comercial, no entanto, não extinguiu a autorização para que as sociedades anônimas pudessem ser constituídas e operar. Esta mudança veio quase trinta anos depois da promulgação do Código Comercial, com a promulgação em 4 de novembro de 1882 da Lei 3.150 que, enfim, autorizou que sociedades anônimas criadas a partir daquela data não precisassem mais da prévia autorização governamental ${ }^{3}$, mas que somente observassem parâmetros legais para sua constituição.

Nesta fase, da liberdade empresarial, as sociedades anônimas (e as sociedades empresárias em geral) puderam finalmente ser usadas por uma parte considerável da população, para proteger seu patrimônio da pessoa física e poder se associar com diferentes sócios com a intenção de obter lucros.

\footnotetext{
${ }^{3}$ Art. $1^{\circ}$ As companhias ou sociedades anonymas, quer o seu objecto seja commercial quer civil, se podem estabelecer sem autorização do Governo.
} 
Em outro parâmetro, no final do século dezenove e começo do século vinte, a economia norte-americana já estava se consolidando como a grande potência mundial, se preparando para o grande "boom" econômico da década de 1920, que só cresceria com o regime de isolacionismo implementado com o fim da Primeira Guerra Mundial e que, eventualmente, resultaria na Grande Depressão após a crise económica mundial de 1929.

De volta ao cenário brasileiro, as leis comerciais da época eventualmente ficaram saturadas e obsoletas em meados do século vinte, quando o Código Civil de 1916 e o Código Comercial de 1850 não conseguiam mais suprir todas as questões e divergências jurídicas e econômicas relacionadas a todos os tipos de sociedades.

Deste modo, o legislador na década de 1970, guiados pelos ensinamentos dos juristas Alfredo Lamy e José Luiz Bulhões Pedreira, decidiram trazer inúmeras inovações e soluções para as sociedades anônimas em especifico, com a elaboração da Lei 6.385 de 7 de setembro de 1976, que regulava o mercado de valores mobiliários e criava a CVM e, ainda, da Lei 6404 de 15 de dezembro de 1976 que regulava as sociedades por ações.

As leis foram um marco regulatório brasileiro societário da era moderna e tinham como objetivo regular o mercado de valores mobiliários e as sociedades anônimas, abertas ou fechadas, para incentivar o desenvolvimento econômico do Brasil e solucionar lacunas criadas por normas anteriores.

Dentre os inúmeros mecanismos e regulamentos criados pelas leis de 1976, ganharam destaque as inovações com relação à regulação dos deveres e responsabilidades do acionista controlador, do abuso do poder de controle e dos administradores das sociedades anônimas, assim como os meios de 
responsabilização desses personagens decorrentes de infração à lei ou ao estatuto.

A figura do acionista minoritário em sociedades anônimas abertas e fechadas não ficou esquecido na Lei 6.404/76 que previu, por exemplo, o direito de os acionistas não controladores receberem por suas ações um preço equivalente a, no mínimo, $80 \%$ do preço pago ao controlador no âmbito de uma alienação de controle, positivando o direito do Tag Along no direito brasileiro, definindo a distribuição de dividendos, e, por fim, a possibilidade de eleição de membros dos conselhos de administração e fiscal de forma separada pelos minoritários. ${ }^{4}$

No entanto, o cenário de investimentos no Brasil na década de 1970 ainda não havia decolado, pois o poder acionário dos conglomerados comerciais ainda estava nas mãos de seletos grupos de empresários.

No final da década de 80 e começo de 1990 o Brasil já se consolidava como um país industrializado e atrativo para investidores institucionais, que se preocupavam na governança de suas investidas, diferentemente dos acionistas de companhias familiares, que tinham como único objetivo maximizar os lucros e manter as sociedades sobre seus controles.

Em paralelo, na década de 1970 a economia norte-americana já era completamente dinâmica, com conglomerados empresariais aproveitando a onda da globalização mundial e criando sociedades que dominavam os mercados mundiais em diversas áreas. Neste contexto, as sociedades anônimas norte-americanas, que viam o cidadão comum como o grande tesouro para alavancar o patrimônio das sociedades, começou a investir pesadamente em boas práticas de governança corporativa, incentivando a

\footnotetext{
${ }^{4}$ MARTINS NETO, Carlos. Dispersão Acionária, Tomada Hostil de Controle e Poison Pills: Breves Reflexões, Disponível em: <http://www.bocater.com.br/UPLOAD/noticias/564d93f37f654.pdf> Acesso em 25 de fevereiro de 2016.
} 
transparência na divulgação de resultados pelas sociedades, atraindo a população em geral para investir em suas ações.

Foi neste momento que advogados e sociedades norte-americanas, interessadas em melhorar ainda mais sua governança corporativa, especialmente em bancos de investimentos, começaram a restringir a atuação de um acionista controlador em sociedades anônimas e impedir que hostile takeovers fossem realizados.

O mecanismo popularmente conhecido como Poison Pill, criado pelo advogado Martin Lipton sócio do escritório Wachtell, Lipton, Rosen \& Katz especializado em fusões e aquisições, tinha como objetivo fundamental pulverizar o capital social da companhia, tentando coibir práticas de tomadas hostis do controle de sociedades no Estados Unidos, para que a companhia tivesse majoritariamente acionistas que pensassem e agissem em prol da sociedade e não puramente em prol de seus próprios interesses.

A prática jurídica e econômica brasileira, com o passar dos anos, foi se aprimorando para tentar chegar a níveis norte-americanos, em que a transparência aos acionistas minoritários se tornou de fundamental importância. As exigências de transparência na divulgação de resultados em instruções normativas publicadas pela CVM, a criação de diferentes níveis de governança corporativa da BMF\&BOVESPA, como a criação do Novo Mercado em 2000, além do Código de Boas Práticas do Instituto Brasileiro de Governança Corporativa - IBGC, mostram que o cenário brasileiro de transparência ao acionista está caminhando para se tornar um pouco mais parecido com o sistema norte-americano.

A governança corporativa de sociedades brasileiras, os mecanismos de dispersão acionária e as tentativas de combate à praticas que incentivem as tomadas hostis de controle ainda são, comparativamente, pequenas em relação ao cenário norte-americano. 
O modelo norte-americano de formas de defender a dispersão acionária e impedir que terceiros tomem o controle de sociedades de forma hostil evoluiu muito e continua evoluindo, e os diversos mecanismos ainda são matéria de muito estudo e controvérsia em âmbitos doutrinários, regulamentares pela SEC e CVM, judiciário. 


\section{CAPÍTULO 1 - CONSIDERAÇÕES SOBRE O PODER DE CONTROLE E DISPERSÃO ACIONÁRIA}

O poder de controle das sociedades anônimas brasileiras tem orginalmente seu começo centrado na ideia em que uma família era tradicionalmente a detentora de toda ou da maioria do poder de controle sobre a gerência de tal sociedade. Séculos se passaram e a realidade teve mudanças paradoxais que merecem a devida análise.

Atualmente, o cenário brasileiro das sociedades anônimas ainda tem em sua maioria esmagadora a situação em que um acionista único ou grupo de acionistas, seja pessoa física ou jurídica ou um bloco de controle, detém a maioria do capital social votante da sociedade anônima, tendo, desta forma o controle das decisões da companhia.

Neste sentido, e tentando simplificar o poder de controle nas sociedades anônimas, José Edwaldo Tavares Borba, foi além, ao definir simplesmente que "Controla uma sociedade quem detém o poder de comandá-la, escolhendo os seus administradores e definindo as linhas básicas de sua atuação." 5

A Lei 6404/76 foi, correta, em partes, na sua abordagem e definição ao poder de controle, pois conseguiu sintetizar no artigo 116 diversas formas de se caracterizar o acionista controlador mas acabou deixando de lado algumas outras maneiras de exercer o poder de controle.

Isso ocorre, pois o artigo $116^{6}$ da Lei 6.404/76 distinguiu que a definição de acionista controlador de uma sociedade anônima não é

\footnotetext{
${ }^{5}$ BORBA, José Edwaldo Tavares. Direito Societário. 14ª ed Editora Atlas, 2015, p. 341.

${ }^{6}$ Art. 116. Entende-se por acionista controlador a pessoa, natural ou jurídica, ou o grupo de pessoas vinculadas por acordo de voto, ou sob controle comum, que:

a) é titular de direitos de sócio que lhe assegurem, de modo permanente, a maioria dos votos nas deliberações da assembléia-geral e o poder de eleger a maioria dos administradores da companhia; e b) usa efetivamente seu poder para dirigir as atividades sociais e orientar o funcionamento dos órgãos da companhia.
} 
caracterizada somente pela simples detenção da maioria do capital social e sim por diversas outras formas.

Numa análise do artigo 116 da Lei 6.404/76 é necessário esclarecer todos os pontos que este artigo trouxe para definir o acionista controlador das sociedades anônimas.

O artigo 116 da Lei 6.404/76 estabeleceu que o acionista controlador pode ser uma pessoa natural e jurídica, e ainda, "grupo de pessoas vinculadas por acordo de voto, ou sob controle comum". Esta definição positivada no caput do artigo 116 da Lei 6.404/74 permitiu que o acionista controlador fosse caracterizado como não somente um acionista, mas sim um grupo de pessoas ou sociedades que agem com a intenção de votar em blocos nas deliberações sociais.

Note que o acordo de votos do artigo 116 da Lei 6.404/76 não está necessariamente relacionado a um acordo de acionistas celebrado de forma formal nos termos do artigo $118^{7}$ da Lei 6.404/76. O acordo de votos pode ser um acordo informal entre acionistas para exercer o direito de voto em um mesmo sentido.

Ou seja, como se vê, a lei trata de três possibilidades de controle da sociedade: (i) o controle detido isoladamente por pessoa física ou jurídica, (ii) o detido por grupo de pessoas unidas por acordo de acionistas, e (iii) o exercido diretamente por um grupo de pessoas jurídicas, controladas por um controlador comum, que então controlará a sociedade indiretamente. ${ }^{8}$

Parágrafo único. O acionista controlador deve usar o poder com o fim de fazer a companhia realizar o seu objeto e cumprir sua função social, e tem deveres e responsabilidades para com os demais acionistas da empresa, os que nela trabalham e para com a comunidade em que atua, cujos direitos e interesses deve lealmente respeitar e atender.

7 Art. 118. Os acordos de acionistas, sobre a compra e venda de suas ações, preferência para adquiri-las, exercício do direito a voto, ou do poder de controle deverão ser observados pela companhia quando arquivados na sua sede.

${ }^{8}$ Colegiado CVM. Proc2001/10329, Reg. 3528/02, Rel. Diretor Marcelo Trindade, j. 19.2.2002. 
Ressalta-se que a CVM, por meio do Parecer CVM/SJU n. ${ }^{\circ}$ 066/85 e da decisão em caso julgado sedimentou seu entendimento com relação ao grupo de acionistas positivado no artigo 116 da Lei 6.404/76.

\begin{abstract}
"É irrelevante para a caracterização do poder de controle a circunstância de que cada um dos cedentes não detenha individualmente aquele poder, visto que bastaria a concentração de vários acionistas de modo a lhes assegurar a preponderância nas deliberações assembleares, vinculados entre si por acordo ou outro pacto, escrito ou informal, conforme $\mathrm{CVM} / \mathrm{SJU} / \mathrm{N}^{\circ}$ entendimento da $\mathrm{CVM}$ 086/82, dentre outros."
\end{abstract}

O artigo 116 da Lei 6.404/76 ao não definir controlador direto, previu a figura do controlador indireto, e a CVM no julgamento do Processo Administrativo Sancionador RJ28/03 definiu que "Para que uma pessoa seja considerada controladora indireta, ela deve controlar o veículo, por meio do qual a companhia objeto é controlada", esclarecendo a figura do controlador indireto.

A lei 6.404/76, ainda, definiu o acionista controlador com o acionista (i) que detém de forma permanente o poder de aprovação de matérias em assembleias gerais e que, (ii) usa efetivamente seu poder para dirigir as atividades sociais e orientar o funcionamento dos órgãos da companhia. 


\section{CAPÍTULO 2 - PODER DE CONTROLE E AS SUAS PRINCIPAIS FORMAS CONTEMPORÂNEAS}

\subsection{PODER DE CONTROLE EXTERNO}

A Lei $6.404 / 76$, foi omissa com relação a uma espécie de poder de controle que merece uma análise mais profunda. Trata-se da espécie de controle denominada de controle externo, em que pessoas ou sociedades que não estão diretamente vinculadas ao capital social da companhia detém seu controle fictício.

Nesta classificação, geralmente estão enquadradas sociedades credoras ou grandes clientes e fornecedores, que, mesmo não participando do capital social da companhia, tem significativa influência da sociedade anônima.

De forma exemplificativa, uma sociedade que produz navios petroleiros e tem como única cliente para a venda de navios a Petrobras, pode ter a Petrobras como controladora externa da sociedade, pois mesmo não tendo participação direta ou indireta na companhia, pode decidir os rumos da companhia ao alterar sua política de compra de navios.

O controle externo da Companhia é ainda mais frequente em casos que o alto grau de endividamento da companhia leva a credores, que mesmo não necessariamente detendo titularidade de participação no capital social da companhia, detém o poder de controle na companhia.

Nesses casos os credores da companhia podem ditar os rumos negociais da companhia ao criar condições para a liquidação do crédito a seu favor. O crédito contra a Companhia pode ser tão influente que os administradores e acionistas da companhia necessitam, em alguns casos, do aval dos credores para poder tomar decisões com relação as ações. 
Em casos extremos, em que a companhia requer a recuperação judicial ao juízo falimentar, os credores mesmo não tendo participação direta no capital social da companhia podem ter direta influência nas decisões da companhia uma vez que para diversos atos é necessária a aprovação da assembleia geral de credores.

\subsection{CONTROLE TOTALITÁRIO}

O controle totalitário da sociedade anônima é a forma mais simples de controle de uma sociedade anônima. No controle totalitário, as ações de emissão de uma sociedade anônima que compõem o capital votante são em sua totalidade detidas por um único acionista ou por um grupo de acionistas vinculados, na forma do art. 116 da Lei 6.404/76.

Note que o controle totalitário não necessariamente está vinculado à totalidade do capital social detido por um acionista e sim pela totalidade do capital social votante detido por um grupo de acionistas vinculados. Isso ocorre, pois em companhias que possuem ações preferenciais compondo parte de seu capital social, as mesmas podem não deter poder de voto nas deliberações sociais, deixando o poder de voto somente com as ações ordinárias.

Desta forma, é comum situações em que um acionista que detém a totalidade do capital social votante da companhia, detendo todas as ações ordinárias, ao tentar capitalizar a sociedade, emite ações preferenciais, sem poder de voto, ao mercado numa tentativa de que investidores interessados nas vantagens outorgadas por ações preferenciais, comprem as ações, injetando capital na companhia. Neste caso a companhia continua sendo controlada de forma totalitária por um acionista, pois este detém a totalidade do poder de voto.

Um dos exemplos de atuação do controle totalitário e de um tipo de sociedade que está sob controle totalitário é denominada subsidiária integral 
e suas ações só podem ter como titular sociedade brasileira, na forma do artigo 251 da Lei 6.404/76. ${ }^{9}$

Note que esta restrição para que o único acionista seja brasileiro é unicamente para o seu controle direto, ou seja unicamente para o acionista controlador direto. $\mathrm{O}$ controle indireto da sociedade pode ser exercido por sociedade estrangeira. ${ }^{10}$

Há de se ressaltar que em sociedades controladas unicamente por um acionista, denominadas de subsidiárias integrais, a regra básica do direito comercial da autonomia patrimonial das sociedades ainda continua plenamente em vigor.

Na sociedade controlada de forma totalitária, quando o patrimônio está integralizado e a sociedade está constituída, a sociedade assume inteiramente os riscos da atividade empresarial perante terceiros, separandose do patrimônio de sua controladora.

\subsection{CONTROLE MAJORITÁRIO}

O controle majoritário é a forma de controle mais comum em sociedades brasileiras. O controle majoritário é a forma de controle que o legislador brasileiro, o judiciário e a CVM mais tentou regular e criar formas de caracterizar o acionista controlador.

As sociedades brasileiras têm, em regra e por essência, a figura de um acionista ou grupo de acionistas que controla as deliberações sociais da companhia decidindo seus rumos empresariais. Objeto de muito estudo, vasta doutrina e inúmeras decisões tanto do poder judiciário quanto da

\footnotetext{
${ }^{9}$ Art. 251. A companhia pode ser constituída, mediante escritura pública, tendo como único acionista sociedade brasileira.

${ }^{10}$ A exigência do legislador de que a sociedade controladora seja brasileira significa que deve ser sediada no País, independentemente, portanto, de seu controle estar em mãos de outras sociedades ou pessoas físicas residentes for a do País ou estrangeiras"

CARVALHOSA, Modesto. Comentários à Lei das Sociedades Anônimas. vol. $4^{\circ}$, p. 121.
} 
CVM, o poder de controle por acionista majoritário se consolidou na atividade empresarial brasileira como a principal forma de se exercer controle sobre uma sociedade.

O artigo 116 da Lei 6.404/76 teve por excelência tentar definir o acionista controlador levando em conta a posição de titular da maioria das ações votantes de emissão de uma sociedade. É impossível proceder o estudo da forma de controle de sociedades brasileiras sem diretamente vincular ao controle majoritário.

Note que o controle majoritário é a forma mais comum de controle tanto no âmbito de sociedades de capital aberto quanto em sociedades com o capital fechado.

No controle majoritário, como mencionado acima, um acionista ou um grupo de pessoas, vinculados por acordo ou não, exercem o controle da sociedade ao votar com mais de cinquenta por cento do capital social votante da companhia no mesmo sentido. Nesta forma de controle, o bloco de controle exerce o poder de controle em todas as deliberações sociais e em todos os órgãos de administração da sociedade.

Isso ocorre, pois, os cargos eleitos pelos acionistas da companhia, como o Conselho de Administração, o Conselho Fiscal e demais órgãos facultativamente criados (comitês, etc.), o bloco de controle sempre poderá eleger a maioria dos seus membros. Neste sentido, o acionista majoritário sempre terá dentro dos órgãos de administração da Companhia, integrantes eleitos por ele, que seguem instruções de como se administrar a sociedade de acordo com a vontade do acionista majoritário.

Os membros eleitos pelos acionistas minoritários, não tendo a maioria do conselho de administração devem colaborar e, ainda, devem fiscalizar as decisões tomadas pelos administradores eleitos pelo acionista majoritário. Este papel de fiscalizador dos atos da administração do 
acionista majoritário compõe importante papel na função dos acionistas minoritários nas sociedades em que o controle é majoritariamente detido por um bloco de controle.

Há de se ressaltar que o dever de lealdade e o dever de diligência dos administradores das companhias deve ser diretamente vinculado à própria companhia e não ao grupo de acionistas que elegeu o administrador. O artigo $154^{11}$ da Lei $6.404 / 76$ sedimentou este ponto, ao esclarecer no parágrafo primeiro que "administrador eleito por grupo ou classe de acionistas tem, para com a companhia, os mesmos deveres que os demais", ou seja, é vedado o favorecimento por membros da administração para um acionista ou grupo de acionistas.

O papel de fiscalização, inclusive, deve ser exercido em todos os órgãos da companhia, pois pode ser executado pelo próprio acionista na assembleia geral, pelos conselheiros de administração no âmbito do conselho de administração e dos conselheiros fiscais em atos de competência do Conselho Fiscal.

Neste sentido, o poder de controle majoritário, comum tanto no Brasil e nos Estados Unidos, se tornou alvo de muitas críticas com relação ao desenvolvimento de uma cultura de governança corporativa sadia e transparente no âmbito das sociedades anônimas.

Ocorre que o acionista que detém a maioria do capital social votante da companhia, e o poder de controlar suas decisões, tendem a tomar decisões que o beneficiem diretamente para poder tirar o máximo de proveito econômico e de influência na sociedade e não necessariamente está

\footnotetext{
${ }^{11}$ Art. 154. O administrador deve exercer as atribuições que a lei e o estatuto lhe conferem para lograr os fins e no interesse da companhia, satisfeitas as exigências do bem público e da função social da empresa.

$\S 1^{\circ} \mathrm{O}$ administrador eleito por grupo ou classe de acionistas tem, para com a companhia, os mesmos deveres que os demais, não podendo, ainda que para defesa do interesse dos que o elegeram, faltar a esses deveres
} 
agindo de forma benéfica para a sociedade em si ou para os demais acionistas.

A sociedade que está diretamente sob o controle de um acionista único ou sob controle de um bloco de acionistas acaba tendo que direcionar suas decisões empresariais para satisfazer as necessidades do acionista controlador e não necessariamente para tirar o máximo proveito de suas atividades econômicas.

Neste sentido, o legislador e, especialmente, a CVM criaram mecanismos para se democratizar e aumentar o nível de transparência nas sociedades anônimas, para que os acionistas minoritários e o mercado em geral pudessem fiscalizar e estar a par de que o capital investido na sociedade estava sendo usado para satisfazer os negócios da sociedade e não somente do acionista controlador. Os exemplos são inúmeros, como a inclusão do artigo $116-\mathrm{A}^{12}$ na Lei $6.404 / 76$, por meio da Lei 10.303 , de 2001, que criou obrigações ao acionista controlador na eleição de membros do Conselho de Administração.

O legislador também foi preciso em inserir o artigo $117^{13}$ na Lei 6.404/76 que definiu as responsabilidades do acionista controlador, que via

\footnotetext{
${ }^{12}$ Art. 116-A. O acionista controlador da companhia aberta e os acionistas, ou grupo de acionistas, que elegerem membro do conselho de administração ou membro do conselho fiscal, deverão informar imediatamente as modificações em sua posição acionária na companhia à Comissão de Valores Mobiliários e às Bolsas de Valores ou entidades do mercado de balcão organizado nas quais os valores mobiliários de emissão da companhia estejam admitidos à negociação, nas condições e na forma determinadas pela Comissão de Valores Mobiliários

${ }^{13}$ Art. 117. O acionista controlador responde pelos danos causados por atos praticados com abuso de poder.

$\S 1^{\circ}$ São modalidades de exercício abusivo de poder: a) orientar a companhia para fim estranho ao objeto social ou lesivo ao interesse nacional, ou levá-la a favorecer outra sociedade, brasileira ou estrangeira, em prejuízo da participação dos acionistas minoritários nos lucros ou no acervo da companhia, ou da economia nacional;

b) promover a liquidação de companhia próspera, ou a transformação, incorporação, fusão ou cisão da companhia, com o fim de obter, para si ou para outrem, vantagem indevida, em prejuízo dos demais acionistas, dos que trabalham na empresa ou dos investidores em valores mobiliários emitidos pela companhia;

c) promover alteração estatutária, emissão de valores mobiliários ou adoção de políticas ou decisões que não tenham por fim o interesse da companhia e visem a causar prejuízo a acionistas minoritários, aos que trabalham na empresa ou aos investidores em valores mobiliários emitidos pela companhia;

d) eleger administrador ou fiscal que sabe inapto, moral ou tecnicamente;
} 
de regra, é o acionista com o controle majoritário na sociedade, para garantir lealdade à Companhia.

\subsection{CONTROLE MINORITÁRIO}

A Revista Capital Aberto, em estudo realizado em $2013^{14}$, observou a mudança de parâmetros das sociedades anônimas de capital aberto no Brasil. Este estudo observou que 56 das 128 sociedades anônimas listadas no segmento do Novo Mercado da BM\&FBovespa não possuíam um acionista controlador, com mais da metade do capital social votante da companhia.

Este número ainda pequeno comparado com toda a realidade empresarial brasileira, mas o número de $44 \%$ de companhias no Novo Mercado sem um controlador estabelecido mostrou que o mercado brasileiro caminha em passos curtos para o desenvolvimento do controle minoritário das companhias.

Nas palavras de Nelson Eizirik, o controle minoritário faz-se presente quando um acionista ou grupo de acionistas exerce o poder de controle com menos da metade do capital votante, e isso ocorre tanto nos casos em que as ações de emissão da companhia estão dispersas no mercado, de maneira que nenhum outro acionista ou grupo de acionistas

e) induzir, ou tentar induzir, administrador ou fiscal a praticar ato ilegal, ou, descumprindo seus deveres definidos nesta Lei e no estatuto, promover, contra o interesse da companhia, sua ratificação pela assembléia-geral;

f) contratar com a companhia, diretamente ou através de outrem, ou de sociedade na qual tenha interesse, em condições de favorecimento ou não equitativas;

g) aprovar ou fazer aprovar contas irregulares de administradores, por favorecimento pessoal, ou deixar de apurar denúncia que saiba ou devesse saber procedente, ou que justifique fundada suspeita de irregularidade.

h) subscrever ações, para os fins do disposto no art. 170, com a realização em bens estranhos ao objeto social da companhia.

$\S 2^{\circ}$ No caso da alínea e do $\S 1^{\circ}$, o administrador ou fiscal que praticar o ato ilegal responde solidariamente com o acionista controlador.

$\S 3^{\circ} \mathrm{O}$ acionista controlador que exerce cargo de administrador ou fiscal tem também os deveres e responsabilidades próprios do cargo.

${ }^{14}$ REVISTA CAPITAL ABERTO. Anuário de Governança Corporativa das Companhias Aberta. p. 14. 
está organizado ou detém número relevante de ações com direito de voto, quanto nos casos em que o acionista majoritário se abstém e não exerce efetivamente o poder de controle. ${ }^{15}$

O controle minoritário, desta forma, se caracteriza pela forma de controle em que um acionista ou um grupo de acionistas exerçam o poder de controle da sociedade detendo menos de 50\% do capital social da sociedade.

A lei 6.404/76 não fez distinção entre o acionista majoritário e os demais acionistas, mas não abordou diretamente os demais tipos de controle, deixando o ordenamento jurídico com lacunas quando se analisa o controle minoritário das sociedades anônimas. Como a forma de controle mais comum nas sociedades brasileiras sempre foi a forma de controle majoritário, o controle minoritário demorou a ser regrado como presente no ordenamento jurídico brasileiro. No entanto, atualmente a vasta maioria da doutrina entende pela existência do controle minoritário no ordenamento jurídico brasileiro.

Alfredo Lamy e José Luiz Bulhões Pedreira ${ }^{16}$, em parecer sobre o poder de controle exercido em uma joint venture analisaram que a Lei 6.404/76 ao definir o acionista controlador definiu como o acionista que (i) tem a predominância dos votos nas assembleias gerais, com a eleição da maioria dos administradores; (ii) tem a permanência dessa predominância e (iii) tem o uso efetivo do poder de dominação, mas não definiu porcentagens deixou em aberto a possibilidade de controle minoritário, não usando o critério numérico para definir.

Neste sentido, Alfredo Lamy e José Luiz Bulhões Pedreira entenderam que a Lei 6.404/76 estabeleceu que o controle seria exercido

${ }^{15}$ EIZIRIK, Nelson. Aquisição de Controle. Inexigibilidade de Oferta Pública. In CASTRO, Rodrigo R. Monteiro de; ARAGÃO, Leandro Santos de. (Coord.). Direito Societário. Desafios atuais. São Paulo: Quartier Latin, 2009, p. 180.

${ }^{16}$ LAMY FILHO, Alfredo; BULHÕES PEDREIRA, José Luiz. A Lei das S.A.: pressupostos, elaboração, aplicação. Rio de Janeiro: Renovar, 1992, p. 426. 
por quem efetivamente tivesse a maioria dos votos nas assembleias gerais, sendo desta forma, não necessariamente quem detém a maioria das ações. $\mathrm{O}$ trecho abaixo demonstra o pensamento dos dois doutrinadores, pois é descrito que detém o controle da sociedade é quem efetivamente usa seu poder de voto para controlar a sociedade, mesmo não necessariamente tendo a maioria das ações do capital social votante:

E, quando o capital está disperso, o minoritário, em relação ao capital social, que tiver maioria nas assembleias gerais (por ausência dos acionistas, ou por exercício de procuratório) de modo permanente, e usar do poder que lhe advém desse fato, estará no exercício do poder de controle da sociedade, e como tal, responderá como "acionista controlador"

A existência de controle minoritário no Brasil no mesmo sentido que Alfredo Lamy e José Luiz Bulhões de Pedreira também foi analisado, dentre outros, por José Waldecy Lucena.

José Waldecy Lucena ${ }^{18}$ de forma muito similar a Alfredo Lamy e José Luiz Bulhões de Pedreira ressaltava que, em decorrência da pulverização do capital social de grandes companhias no Brasil o controle de tal sociedade poderia ser exercido por uma minoria ativa, detendo menos de $50 \%$ do capital social votante da mesma companhia.

Isso ocorria, pois esta minoria, mesmo formada por acionistas que não representavam mais de $50 \%$ do capital social da companhia conseguia exercer o controle da sociedade ganhando as deliberações sociais com votações com menor quórum de aprovação em segundas convocações.

Quando se analisa o controle minoritário no Brasil é necessário expor a visão da CVM neste quesito. A CVM até 2009 não tinha abordado de forma ampla e incisiva o controle minoritário em sociedades anônimas. Como a ampla maioria das sociedades abertas tinham um controlador definido, e a CVM não teve muitas oportunidades para analisar a forma de

\footnotetext{
${ }^{17}$ LAMY FILHO; BULHÕES PEDREIRA, 1992, p. 426.

${ }^{18}$ LUCENA, José Waldecy. Das sociedades anônimas. Comentários à lei (artigos $1^{\circ}$ a 120 ). v. 1. Rio de Janeiro: Renovar, 2009, p. 1078.
} 
controle minoritária e se via presa para definir questões em que a forma de controle era ou totalitária ou majoritária, sempre com mais de metade do capital votante.

O leading case para a CVM foi RJ 2009/1956 em que a venda do controle indireto da TIM resultou no pedido de acionistas minoritários da companhia de que a TIM realizasse uma oferta pública de aquisição das ações dos minoritários uma vez que houve uma mudança no controle indireto na TIM.

Para entender a situação fática do caso da TIM, o Diretor-Relator do caso, Eliseu Martins, explicou em seu relatório o caso da seguinte forma:

A TIM Participações S.A (“TIM Participações”) é companhia aberta brasileira, titular de $100 \%$ das ações de emissão da TIM Celular S.A e da TIM Nordeste S.A. Seu controle direto é exercido pela TIM Brasil Serviços e Participações S/A ("TIM Brasil"), detentora de $81,24 \%$ das ações votantes. A TIM Brasil, por sua vez, é subsidiária integral da Telecom Italia Internacional NV, sociedade holandesa, que, por sua vez, é controlada pela Telecom Italia S.p.A. ("Telecom Italia"), companhia aberta italiana. Até a implementação da operação objeto de análise pela CVM, a Olimpia S.p.A (“Olimpia”) era a maior acionista da Telecom Italia, sendo detentora de $17,99 \%$ do seu capital votante.

A Olimpia, por sua vez, tinha como sócios a Pirelli \& C. S.p.A ("Pirelli”), titular de $80 \%$ do seu capital social e a Sintonia S.p.A e Sintonia S.A, que juntas eram titulares dos 20\% restantes do capital (juntas "Sintonia"). Em maio de 2007, um grupo de investidores compostos pelas empresas Assicurazioni Generalli S.p.A., Sintonia S.A., Intesa Sanpaolo S.p.A., Mediobanca S.p.A. e Telefónica S.A., por meio de participação na sociedade italiana Telco S.p.A ("Telco'), acordaram a compra, pela Telco, de $100 \%$ do capital da Olimpia. A transação foi concluída em 25.10.2007, depois de obtidas as aprovações necessárias. Posteriormente, a Olimpia foi incorporada pela Telco, que passou a deter diretamente $24,5 \%$ do capital votante da Telecom Italia. A Telco, também, adquiriu, em março de 2008, nova participação na Telecom Italia, além de ter contribuído ao seu capital 5,6\% das ações ordinárias da Telecom Italia, que eram de titularidade da Mediobanca S.p.A e da Assicurazioni Generalli S.p.A.

Desta forma, diversos acionistas minoritários da TIM Brasil entenderam que a venda de 17,99\% do capital votante da Telecom Itália pela Olimpia S.p.A resultou na venda do controle da Telecom Itália (controladora indireta da TIM Brasil) e consequentemente gerava a 
obrigação da controladora da TIM Brasil realizar uma OPA para aquisição da totalidade das ações da TIM Brasil detidas por acionistas minoritários.

Em difícil decisão e extensos votos a CVM entendeu que neste caso o artigo $254-\mathrm{A}^{19}$ da Lei 6.404/76 não poderia ser usado em uma alienação de controle minoritário. Os diretores da CVM neste caso, tiveram que analisar duas questões fundamentais: se a lei brasileira ou italiana iriam prevalecer e se era o possível obrigar uma sociedade à realizar uma OPA por transferência de controle minoritário.

$\mathrm{O}$ caso julgou ao final que não era necessária a OPA neste caso específico, mas os diretores da CVM basearam suas respostas em argumentos diferentes. A presidente Maria Helena Santana argumentou que neste caso a lei italiana deveria prevalecer, os diretores Eli Loria e Otávio Yazbek sustentaram argumentos parecidos, indicando que o artigo $116 \mathrm{da}$ Lei 6.404/76 que trata sobre o acionista controlador define o acionista controlador como o acionista que detém o poder permanente da companhia, e que neste caso não era possível definir o controlador.

O Relator-Diretor, no entanto, explicou que houve uma mudança nos paradigmas tradicionais de controle majoritário das companhias quando se caracterizou que uma sociedade com menos de $50 \%$ do capital votante da companhia estava à controlando e, indiretamente, controlando a TIM Brasil. Esclarecendo seus argumentos, o Diretor-Relator fez as seguintes ponderações:

No Precedente CBD, o Diretor-relator menciona que, a seu ver, para que o requisito de permanência no poder seja atendido, vencer uma eleição ou preponderar em uma decisão não é suficiente. É necessário que o acionista possa, juridicamente, fazer prevalecer sua vontade sempre que desejar, o que apenas ocorre se o acionista tiver 50\% mais uma das ações com direito a voto. De acordo com essa interpretação, o controle de fato não acarretaria a obrigatoriedade de

\footnotetext{
${ }^{19}$ Art. 254-A. A alienação, direta ou indireta, do controle de companhia aberta somente poderá ser contratada sob a condição, suspensiva ou resolutiva, de que o adquirente se obrigue a fazer oferta pública de aquisição das ações com direito a voto de propriedade dos demais acionistas da companhia, de modo a lhes assegurar o preço no mínimo igual a $80 \%$ (oitenta por cento) do valor pago por ação com direito a voto, integrante do bloco de controle
} 
realização de OPA. Essa interpretação, a meu ver, não merece prosperar. A lei, se quisesse se referir apenas ao controle majoritário, poderia tê-lo feito expressamente ou mesmo se referido à "maioria absoluta" do capital votante da companhia, e não à "maioria dos votos nas deliberações da assembléia-geral" . Nesse sentido, Fábio Konder Comparato, ao analisar o art. 116, menciona que "a fórmula legal abrange o chamado controle minoritário, dado que não se exige a detenção da maioria do capital votante" . A expressão "de modo permanente" parece indicar a necessidade de continuidade ou ininterrupção para a caracterização do controle, mas a lei não determina um prazo mínimo de permanência. (...)

É claro que essa preponderância, no extremo, apenas é garantida nos casos de controle majoritário, pois nesses casos há impossibilidade fática de o controlador encontrar resistência à sua vontade nas assembleias. Mas essa visão extrema não me parece a melhor interpretação do art. 116 e visivelmente esse também não é o entendimento do Prof. Comparato, já que ele admite que o art. 116 engloba o controle minoritário. Nos casos de alta dispersão acionária e forte absenteísmo, existe uma justa expectativa de que um acionista que tenha menos de $50 \%$ mais uma das ações representativas do capital votante da companhia consiga fazer valer sua vontade nas assembleias gerais. Nesse sentido, dadas as circunstâncias do caso concreto e analisando-se o histórico das assembleias da companhia, há forte probabilidade de que o acionista faça valer sua vontade. (grifo nosso) (BRASIL, 2009).

Neste sentido, após o julgamento do Processo CVM RJ 2009/1956, a forma de controle minoritária foi caracterizada no Brasil, mesmo que tendo parâmetro uma sociedade italiana que controlava uma companhia aberta brasileira e mesmo a maioria do colegiado da CVM tendo decidido que não havia exigência para a realização da OPA.

\subsection{CONTROLE GERENCIAL}

O controle gerencial pode ser considerado, atualmente, o método mais avançado de governança corporativa nas sociedades anônimas. O controle gerencial ocorre em sociedades em que o capital é extremamente pulverizado e o controle acaba nas mãos dos administradores eleitos acionistas.

Nas palavras de Erik Frederico Oioli, o controle gerencial representa o extremo da separação entre propriedade acionária e poder de controle, uma vez que se está diante de um poder não fundado na participação 
acionária e que se sobrepõe à vontade (ou à falta de vontade), até então concebida como soberana, dos acionistas. ${ }^{20}$

Este fenômeno de controle empresarial ocorre em casos que os acionistas detêm individualmente uma titularidade tão baixa no capital social votante da companhia que são incapazes de decidir os rumos empresariais da sociedade anônima, pois mesmo com diversos acionistas se juntando não conseguem ultrapassar a metade do capital votante e não conseguem exercer o controle de forma minoritária.

Para Fabio Konder Comparato ${ }^{21}$ em companhias em que o capital é extremamente pulverizado e nenhum acionista ou grupo de acionistas detém ações o suficiente para controlar a sociedade, os administradores eleitos passam a ter a posição de controladores da companhia e os acionistas viram meros prestadores de capital.

Como os acionistas não conseguem se juntar para decidir os rumos da companhia em seus próprios benefícios, as deliberações das companhias que estão sob o controle gerencial tendem a prezar mais pela eficiência econômica da companhia e pela transparência em seus atos e divulgação de resultados.

Fabio Ulhoa Coelho ${ }^{22}$, em seu Curso de Direito Comercial, conclui que no Brasil ainda se predominam as situações em que o controle das sociedades é totalitário e majoritário, que há poucas sociedades com o controle minoritário e que não existem sociedades com o seu controle exercido de forma gerencial. Esta afirmação pode ser fundamentada pelo fato de o mercado de capitais brasileiro ainda não estar completamente maduro para atingir níveis de governança corporativa que incentivem a dispersão acionária como de forma geral.

\footnotetext{
${ }^{20}$ OIOLI, Erik Frederico. Oferta Pública de Aquisição do Controle de Companhias Abertas. Coleção IDSA de Direito Societário e Mercado de Capitais, v. 1. São Paulo: Quartier Latin, 2010, p. 36.

${ }^{21}$ COMPARATO, Fábio Konder. Direito empresarial. São Paulo: ed. Saraiva, 1995, p. 69.

${ }^{22}$ COELHO, Fábio Ulhoa. Curso de direito comercial. São Paulo: ed. Saraiva, 1999, p. 276-277.
} 
No controle gerencial, além da baixa titularidade acionária pelos acionistas individuais, existe também a acentuada passividade exercida pelos acionistas nas assembleias gerais da Companhia. Neste sentido a extrema pulverização do capital social votante da companhia não é o suficiente para que a companhia tenha o controle gerencial como sua forma de controle.

Na companhia com o controle gerencial, exercido pelos membros da administração da companhia, os acionistas ou grupos de acionistas que mesmo detendo o poder de controle da companhia não se juntem e exerçam o controle mediante votos em assembleias gerais. Em casos que os referidos acionistas atuem de forma conjunta e ativamente, mesmo não detendo mais da metade do capital social da companhia, se caracterizaria a forma de controle minoritário e não do controle gerencial.

O controle gerencial resulta de um processo de diferenciação entre investidores empresariais e investidores meramente capitalistas. Em companhias em que a base acionária é composta por acionistas capitalistas, esses estão unicamente interessados nos direitos econômicos oriundos das ações, e não exercem seu poder de voto, resultando nesta passividade que leva ao controle gerencial das companhias.

Nas companhias em que se verifique o controle gerencial, fica necessária a outorga de procurações para que os administradores possam exercer o direito de voto dos acionistas nas assembleias gerais. A outorga de procurações, conhecida como proxys estão reguladas no artigo 126, parágrafo $2^{23}$ da Lei $6.404 / 76$ e permite que os administradores enviem

\footnotetext{
23 Art. 126. As pessoas presentes à assembléia deverão provar a sua qualidade de acionista, observadas as seguintes normas:

$\S 2^{\circ} \mathrm{O}$ pedido de procuração, mediante correspondência, ou anúncio publicado, sem prejuízo da regulamentação que, sobre o assunto vier a baixar a Comissão de Valores Mobiliários, deverá satisfazer aos seguintes requisitos:

a) conter todos os elementos informativos necessários ao exercício do voto pedido;

b) facultar ao acionista o exercício de voto contrário à decisão com indicação de outro procurador para o exercício desse voto;

c) ser dirigido a todos os titulares de ações cujos endereços constem da companhia.
} 
relatórios de metas junto com procurações aos acionistas para que, ao exclusivo critério do acionista, uma procuração seja outorgada para que os administradores da companhia exerçam o poder de voto e consequentemente possam administrar a companhia na forma proposta pelos órgãos da administração. 


\section{CAPÍTULO 3 - CONSIDERAÇÕES SOBRE A AQUISIÇÃO E A TOMADA DE PODER DE CONTROLE.}

Como explicado no capítulo acima, o controle de uma sociedade não é algo da matemática exata em que se torna fácil estabelecer o controle, especialmente em casos de capital pulverizado. Da mesma forma, a tomada de controle das sociedades requer o devido cuidado para se estabelecer a forma de como pode ser feita.

A tomada de controle, primeiramente, pode ser classificada como voluntária ou involuntária. Na tomada de controle voluntária o comprador e o vendedor do capital social votante são livres para negociar a compra e venda das ações da forma que quiserem, estabelecendo preços e condições para a tomada de controle da sociedade.

Por outro lado, na tomada de controle involuntária, o detentor do controle da sociedade tem a perda do controle da companhia por motivos que não são de sua própria vontade. $\mathrm{O}$ falecimento do titular do poder de controle, por exemplo, é uma forma clássica de transferência do controle de forma involuntária.

Outra forma, derivado de cláusulas contratuais, é de quando alguma declaração ou garantia é violada por uma das partes em um contrato de compra e venda de ações, ou alguma outra condição contratual, e, consequentemente, o gatilho para que a outra parte exerça uma opção de compra de ações ocorre.

Nesta hipótese uma das partes é obrigada a vender sua participação no capital social da sociedade e, consequentemente, pode perder o controle da sociedade.

A tomada de controle também pode ser classificada em uma tomada de controle hostil ou amigável. Na tomada de controle de forma amigável, a 
administração da companhia, os acionistas vendedores, e os compradores negociam livremente as condições e o preço da compra das ações, podendo ambas as partes estabelecer condições para que o negócio seja concretizado.

A tomada de controle de forma hostil, conhecido como hostile takeovers, ocorre em situações que a administração da companhia e/ou os acionistas não concordam com a mudança do controle.

$\mathrm{Na}$ tomada de controle de forma hostil o controlador da companhia, ou os acionistas minoritários em companhias que detém o capital pulverizado (com controle minoritário ou gerencial) são a favor de preservar o controle e podem ser contra a mudança da forma de controle ou, ainda, contra o acionista ou grupo de acionistas que pretendem tomar o controle da sociedade.

As medidas para a tomada de controle podem ser feitas de várias formas dependendo das condições da companhia ou do mercado em certo cenário. A tomada de controle pode ser feita de forma escalonada, em que o acionista que deseja tomar controle da sociedade faz a compra das ações em pequenas parcelas, seja em decorrência do alto preço de compra das ações em grande escala, da baixa disponibilidade de ações para compra em free float ou, ainda, em casos de tomada de controle de forma hostil para que a administração e demais acionistas não percebam que o acionista está comprando uma grande quantidade de ações com desejo de tomar o controle da sociedade.

Por outro lado, a tomada de controle em sua forma clássica resulta na negociação entre os acionistas controladores da sociedade e o comprador, numa compra pelas ações detidas pelo bloco de controle. Esta compra, diferentemente da aquisição escalonada de ações consiste na compra em grandes quantidades de participação na sociedade, com preço e condições negociadas diretamente com o acionista controlador. 
Outra forma que de tomada de controle que não necessariamente envolve a compra de ações consiste na negociação para a subscrição de novas ações na companhia. Neste tipo de tomada de controle o acionista que deseja tomar controle da companhia deve propor o aumento do capital social da companhia, numa forma que o aumento do capital social resulte no efeito que o acionista passe a deter a maioria do capital votante da companhia.

Nesta hipótese, a tomada de controle necessariamente está vinculada a tomada de controle de forma amigável, uma vez que será necessária a concordância dos atuais acionistas da companhia para concordar em renunciar o direito de preferência no aumento de capital da companhia.

A tomada de controle, por fim, também pode ser tomada com base em convenções de votos e em acordos em que acionistas pedem a representação de outros acionistas para representá-los em assembleiasgerais. Esse mecanismo que ficou conhecido como Proxy Fight ou briga de procurações permite que um acionista, mesmo não tendo a maioria do capital social em seu patrimônio, pode controlar a companhia usando as ações de outros acionistas.

\subsection{ESPÉCIES DE MECANISMOS DE PROTEÇÃO À TOMADA DE CONTROLE.}

Os mecanismos de defesa às tomadas de controle tiveram o início de seu uso de forma mais abrangente, nos Estados Unidos com o denominado Warrant Dividend Plan, que depois ficou conhecido como a famosa Poison Pill.

Os mecanismos de defesa às tomadas hostis de controle podem ser divididos em dois grupos, entre os mecanismos preventivos - conhecido na doutrina norte-americana como os shark repellents (repelente de tubarões, 
sendo o tubarão, obviamente, o investidor interessado em tomar controle da companhia) - e os mecanismos repressivos.

Nos mecanismos de defesa classificados como preventivos, sua atuação é estabelecida de uma forma para impedir que uma tomada de controle de forma hostil ocorra, antes de qualquer tentativa. Neste sentido, as medidas preventivas atuam para que a companhia fique menos interessante à uma tomada de controle, tornando essa tomada de controle muito complicada ou excessivamente onerosa.

Podem ser classificadas como mecanismos preventivos de tomada de controle os seguintes mecanismos: (i) Staggered Board; (ii) Golden Parachutes; (iii) Accelerated Loans; e (iv) Supermajority Votes.

Por outro lado, existem os mecanismos de defesa às tomadas de controle que são usados quando a tentativa hostil de tomada de controle já está em curso. Esses mecanismos, assim como os mecanismos preventivos tem como função tornar a tomada de controle difícil e excessivamente onerosa.

Nesta categoria, podemos classificar as seguintes medidas como atuantes na forma repressiva: (i) White Knight; (ii) White Squire; (iii) Crown Jewel; (iv) Green Mail; e (v) Pac-Man Defense.

No Brasil, como verificaremos abaixo, muitos destes mecanismos não são usados por uma série de fatores, seja por falta de desenvolvimento do mercado ou por proibição legal ou regulamentar, quando nosso ordenamento jurídico não ofereceu respaldo ao uso de determinados mecanismos de defesa.

Pela falta de desenvolvimento do mercado e pelas questões legais, o mercado brasileiro usa, via de regra, um mecanismo para evitar a tomada de controle, que, neste estudo, usaremos o termo Poison Pill Brasileira para 
descreve-lo - mesmo que, como analisaremos abaixo, a Poison Pill Brasileira tem distintas diferenças da Poison Pill original.

A Poison Pill Brasileira, que será objeto de estudo em seção específica, pode ser usada como um mecanismo preventivo ou repressivo, mas geralmente, tem seu uso mais vinculado a um mecanismo preventivo.

\subsection{POISON PILL}

O método de defesa da Poison Pill pode ser considerado a primeira forma de como uma companhia conseguiu estabelecer certas defesas estatutárias e contratuais que pudessem dificultar a mudança de controle de uma companhia.

O advogado Martin Lipton é conhecido como o pai da Poison Pill norte-americana, quando em 1982, ao defender os interesses da administração de uma companhia que passava por um processo de possível tomada hostil de controle inseriu um mecanismo de prevenção à mudança de controle. Naquela época, Martin Lipton nomeou o mecanismo como Warrant Dividend Plan e posteriormente o mercado iria absorver esse novo mecanismo como a Poison Pill.

O plano elaborado por Martin Lipton tinha como objetivo dificultar e encarecer significantemente o possível ingresso de um novo acionista classificado como hostil para a companhia e seus administradores.

O Warrant Dividend Plan, dividido entre o Flip In e o Flip Over, consistia na outorga de certos direitos aos atuais acionistas da companhiaalvo. Esses direitos atribuídos aos acionistas da companhia teriam seus "gatilhos" acionados quando um investidor realizasse, pelo mercado, oferta para a compra de participação relevante no capital social da companhia.

Os direitos dos acionistas por meio de Warrant Dividend Plan consistiam em, no momento em que o gatilho fosse acionado (a realização 
de uma oferta de compra pelo investidor), o direito atribuído por meio do Warrant Dividend Plan era acionado em que o acionista tinha a opção de comprar ações da companhia ou ações do terceiro investidor interessado em tomar o controle da companhia. A outorga desses direitos incluía a opção de comprar as ações da companhia ou do investidor por um preço muito inferior ao preço praticado no mercado.

O Warrant Didividend Plan, conforme já mencionado pelo seu próprio nome, atribuía esses direitos de opção de compra de ações a título de dividendos, como forma de remuneração aos acionistas.

Desta forma, como na legislação norte-americana o conselho de administração é o órgão competente para deliberar acerca da distribuição de dividendos, o Warrant Dividend Plan poderia ser implementado sem a deliberação dos acionistas.

O nome Poison Pill substituiu o Warrant Dividend Plan em uma declaração de um funcionário de um banco de investimentos que ao ser perguntado por um repórter do Wall Street Journal o que era o Warrant Dividend Plan o funcionário simplesmente respondeu "Uma Poison Pill (uma Pílula Venenosa)"24.

\footnotetext{
24 "In September 1982 Martin Lipton published a memorandum describing the "Warrant Dividend Plan". The "warrant" of the "Warrant Dividend Plan" was a security that could be issued by the board of directors of a target company that would have the effect of increasing the time available to the board to react to an unsolicited bid and allowing the board to maintain control over the process of responding to the bid. In various forms it was used successfully by targets of hostile bids in 1982 and 1983 to gain time and maximize shareholder value. In 1983 Mr. Lipton's plan was christened with the unfortunate name, "Poison Pill" by an investment banker who had nothing to do with its creation, but who, when asked by a Wall Street Journal reporter what a security (modeled on the Warrant Dividend Plan) issued by Lenox, Inc. on the advice of Mr. Lipton was called, responded flippantly "a poison pill". LIPTON, Martin; ROWE, Paul K. Pills. Polls and professors: a reply to professor Gilson. New York: New York University Center for Law and Business, Apr. 2001, p. 13. Disponível em:

<http://papers.ssrn.com/paper.taf?abstract_id=268520>. Acesso em: 10 jul. 2009.
} 


\subsection{FLIP IN E FLIP OVER}

O mecanismo da Poison Pill conhecido como Flip In é o resultado de uma série de benefícios existentes aos atuais acionistas da Companhia para impedir a tomada de controle de terceiros nas companhias.

Na modalidade Flip In os acionistas e administração da companhia elaboram no plano da Poison Pill formas de aumentar a quantidade necessária de ações para que um terceiro tome controle da companhia e, ainda, elaboram uma forma de diluir a participação de um acionista que esteja interessado em adquirir o controle da companhia.

Classicamente, nas Poison Pills em que a modalidade de Flip In está em vigor, a companhia que está com a possibilidade de ter seu controle alterado permite que os acionistas, com exceção ao acionista adquirente, tenham a possibilidade de adquirir ações de emissão da companhia que estão mantidas na tesouraria por um preço inferior ao preço praticado no mercado ou, ainda, a subscreverem ações a serem emitidas em aumento de capital social por valores inferiores ao valor de mercado. ${ }^{25}$

A modalidade Flip Over da Poison Pill pode ser considerada uma modalidade de Poison Pill em que o gatilho para a defesa dos direitos dos acionistas da companhia-alvo é acionado após a tentativa de tomada hostil de controle. Na modalidade Flip Over da Poison Pill são atribuídos certos direitos à acionistas da Companhia que está ameaçada de ter seu controle alterado, assegurando aos acionistas atuais da companhia proteção em caso de compra de ações por terceiro, garantindo a estes terceiros a possibilidade de poder comprar a participação do investidor interessado em adquirir o controle da companhia por um preço mais baixo que o praticado no mercado.

\footnotetext{
${ }^{25}$ BARROSO DO NASCIMENTO, João Pedro. Medidas Defensivas à Tomada de Controle de Companhias. Quartier Latin, 2011.pag. 143
} 
A modalidade Flip Over está direcionada para o terceiro que, após a aquisição de volume significante de ações da companhia-alvo, realize operação de concentração empresarial (para tomar controle, como fusão, incorporação) e os direitos constantes no estatuto da companhia possam ser exercidos pelos acionistas titulares de ações antes da entrada do terceiro na companhia.

Neste sentido a operação de concentração empresarial - em que o terceiro ingressa na companhia e após a operação toma o controle ou passa a ter participação elevada na companhia - só poderá ser realizada com a garantia de que os acionistas da companhia recebem ações da companhia resultante da concentração empresarial.

Na Poison Pill com Flip Over existe um pressuposto que a operação de concentração empresarial resultará na sucessão universal dos direitos e obrigações da companhia adquirida. Para isso ocorrer nos casos de Poison Pill com Flip Over o gatilho para o exercício da cláusula de Flip Over geralmente ocorre quando a aquisição de participação acionária na companhia-alvo fica em torno de $20 \%$ do capital votante, e tem como principal objetivo a garantia dos acionistas da companhia-alvo de adquirir ações do adquirente por um preço abaixo dos padrões do mercado.

\subsection{MECANISMOS PREVENTIVOS}

\subsubsection{STAGGERED BOARD - CONSELHO DE ADMINISTRAÇÃO ALTERNADO}

O Staggered Board é reconhecido pela prática jurídica norteamericana como uma das mais modernas e eficientes maneiras de evitar o controle majoritário ou totalitário em uma companhia. Nos EUA a prática do Staggered Board tem se provado eficiente e já é implementada em 
diversas companhias, especialmente nas companhias em que o controle gerencial prevalece como a forma de controle da companhia.

O Staggered Board, que pode ser traduzido como o Conselho de Administração Alternado, consiste na prática de separar os membros do conselho de administração da companhia em mandatos com períodos diferentes, em que os membros do conselho de administração são divididos em diferentes classes.

Na prática do Staggered Board, as classes e o mandato dos membros do conselho de administração deve constar do estatuto social da companhia, especificando que os mandatos de cada classe não podem ser compatíveis com outra classe. Desta forma, uma classe de membros do conselho de administração nunca é eleita ao mesmo tempo e com o mesmo tempo de gestão da outra.

Outra característica do Staggered Board é que, para evitar que um acionista tome controle da companhia e em seguida demita a totalidade dos membros do conselho de administração para eleger seus próprios membros de confiança, o estatuto social da companhia pode prever que os membros do conselho de administração só podem ser destituídos sob justa causa, impedindo a demissão imotivada.

No Staggered Board a defesa da companhia e de seus acionistas consiste na garantia de saber que quando um acionista conseguir adquirir participação relevante na companhia, ou até o controle da companhia, ele não poderá eleger a maioria do conselho de administração da companhia em certos períodos, uma vez que o mandato dos membros do conselho de administração não é compatível com os demais, eleitos em classes diferentes.

No Brasil, o Staggered Board pode ficar somente no campo teórico, uma vez que com base na nossa legislação torna sua atuação é inviável. Isso 
ocorre, pois na legislação brasileira, mais precisamente o artigo $140^{26}$, caput, da Lei 6.404/76 estabelece que os membros do conselho de administração são destituíveis a qualquer tempo pela assembleia geral de acionistas.

Desta forma, uma cláusula no estatuto social que estabelece que o membro do conselho de administração só poderá ser destituído mediante justa causa poderia ser considerada ilegal para fins da legislação brasileira. Consequentemente, não é possível estabelecer que o acionista majoritário não tenha a maioria dos membros do conselho de administração da companhia.

\subsubsection{GOLDEN PARACHUTE - PARAQUEDAS DOURADO}

O Golden Parachute, com a tradução literal para Paraquedas Dourado, pode ser mais detalhadamente descrito como um plano de retenção de executivos com condições especiais.

A defesa do tipo Golden Parachute consiste em definir para a administração da companhia e seus altos executivos certas opções e métodos de compensação financeira com a condicionante de que estes planos ou essas opções entram em vigor caso ocorra uma mudança no controle da companhia.

Neste sentido um potencial adquirente do controle da companhia, ao tomar ciência da existência desses planos de retenção e compensação de executivos pode ficar desmotivada em adquirir a relevante participação, ao perceber que (i) terá que desembolsar capital para cumprir estes planos e (ii) poderá ficar obrigada a manter certos executivos na companhia, ao invés de executivos escolhidos pelo novo investidor.

\footnotetext{
${ }^{26}$ Art. 140. O conselho de administração será composto por, no mínimo, 3 (três) membros, eleitos pela assembléia-geral e por ela destituíveis a qualquer tempo, devendo o estatuto estabelecer:
} 
O Golden Parachute, com bases similares ao plano de Crown Jewel (que será detalhadamente descrito abaixo), sofre certas resistências por parte da doutrina. Ocorre que a outorga de benefícios injustificada para administradores da companhia, com o único objetivo de deixar a companhia menos atrativa para terceiros investidores em uma possível tomada hostil, pode ser considerada um abuso do poder de controle e dificilmente teria sua legalidade confirmada pelo poder judiciário.

Assim como no Crown Jewel o dano hipotético que a tomada de controle pode ocasionar na companhia não pode ser argumento suficiente para estabelecer planos de retenção de executivos fora dos padrões dos mercados em condições que não retratem a condição financeira da companhia.

$\mathrm{Na}$ forma do artigo 117, parágrafo 1, alínea (c) ${ }^{27}$ da Lei 6.404/76 constitui como modalidade do abuso de poder do acionista controlador a adoção de políticas que não tenham por fim o interesse da empresa ou que possam lesar acionistas minoritários ou investidores.

Neste sentido, os acionistas minoritários da companhia, não preocupados com a mudança de controle e somente com os rendimentos de suas ações com dividendos distribuídos pela companhia, poderiam considerar como forma de abuso de poder do controlador a outorga de benefícios excessivos aos administradores da companhia somente para dificultar uma eventual mudança do controle da companhia.

\footnotetext{
${ }^{27}$ Art. 117. O acionista controlador responde pelos danos causados por atos praticados com abuso de poder.

$\S 1^{\circ}$ São modalidades de exercício abusivo de poder:

c) promover alteração estatutária, emissão de valores mobiliários ou adoção de políticas ou decisões que não tenham por fim o interesse da companhia e visem a causar prejuízo a acionistas minoritários, aos que trabalham na empresa ou aos investidores em valores mobiliários emitidos pela companhia;
} 


\subsubsection{SUPERMAJORITY VOTES - QUÓRUM QUALIFICADO}

O Supermajority Votes é uma técnica muito comum no direito norteamericano que tende a proteger as companhias com o capital pulverizado. A técnica do Supermajority Votes (com a tradução literal para votos da supermaioria) é uma técnica em que o estatuto social da companhia estabelece quórum qualificado para diversas matérias importantes de interesse da companhia.

A técnica do Supermajority Votes, pode, por exemplo forçar certas matérias a ter uma aprovação de elevados quórums, entre $75 \%$ e a unanimidade, para estabelecer que certa deliberação seja aprovada.

O investidor interessado em tomar controle da companhia pode ficar desinteressado em realizar o investimento na companhia ao verificar que certas matérias de seu interesse necessitarão da aprovação da "super maioria" com elevados quórums, e, consequentemente, o investidor não terá controle sobre todas as deliberações da companhia.

Uma alternativa para fugir do Supermajority Votes seria adquirir a totalidade das ações da companhia. Essa alternativa, no entanto, muitas vezes não é viável, uma vez que torna a aquisição excessivamente onerosa ao investidor.

O Supermajority Votes tem uso no Brasil restringido pelo artigo $136^{28}$ da Lei 6404/76. Nos termos do caput do artigo 136 da Lei 6.404/76, o quórum qualificado "da aprovação de acionistas que representem metade, no mínimo, das ações com direito a voto" já é estabelecido pela lei, e a alteração deste quórum na forma do estatuto só é possível em companhias fechadas.

\footnotetext{
${ }^{28}$ Art. 136. É necessária a aprovação de acionistas que representem metade, no mínimo, das ações com direito a voto, se maior quórum não for exigido pelo estatuto da companhia cujas ações não estejam admitidas à negociação em bolsa ou no mercado de balcão, para deliberação sobre:
} 
Neste sentido, a adoção do Supermajority Votes no ordenamento jurídico brasileiro só é possível em companhias fechadas, em que o estatuto social pode elevar o quórum qualificado para as matérias.

\subsubsection{ACCELERATED LOANS - EMPRÉSTIMOS ACELERADOS}

A técnica dos Accelerated Loans - que pode ser traduzido como empréstimos acelerados ou ainda como empréstimos com vencimento antecipado pela troca de controle- consiste na técnica de inserir nos contratos de empréstimos celebrados pela companhia, cláusulas de vedação à troca de controle. Estes contratos de empréstimo são celebrados com cláusulas que estabelecem que em caso de troca de controle na companhia, o credor poderá acelerar a dívida e vencer antecipadamente o contrato.

Este mecanismo deixa a companhia menos propensa à tomada de controle, uma vez que um terceiro interessado em tomar o controle da companhia teria que avaliar o risco de assumir o controle da sociedade e imediatamente ter seus empréstimos vencidos antecipadamente, tendo a companhia a obrigação de ter que pagar a totalidade do empréstimo.

Todavia, os efeitos deste mecanismo podem ser mitigados por razão da livre negociação entre as partes, com a companhia de um lado e o credor do outro. Este mecanismo, tem sua efetividade reduzida tanto no Brasil quanto em outros países uma vez que como o vencimento antecipado dos contratos de empréstimo é algo negociado com os bancos, o terceiro adquirente pode negociar com o banco e pedir um waiver (pedido de renúncia) com relação à aceleração da dívida por troca de controle e assumir a companhia sem a necessidade de pagar antecipadamente seus empréstimos bancários. 


\subsection{MECANISMOS REPRESSIVOS}

\subsubsection{WHITE KNIGHT - CAVALEIRO BRANCO}

A modalidade defensiva do White Knight ocorre quando uma companhia que está sob o interesse de investimento de um investidor com visões diferentes da administração da companhia em que a administração da companhia convida terceiros investidores para realizar uma oferta concorrente e consequentemente desmotivar o terceiro adquirente hostil de realizar uma oferta às ações da companhia.

No contexto do White Knight a administração da companhia, além de seus acionistas alinhados com a administração, tenta alterar a oferta da aquisição de ações, para um acionista alinhado com as mesmas visões da administração da companhia. Desta forma o White Knight, tem como função realizar uma oferta maior aos acionistas para tentar substituir o terceiro investidor hostil e realizar uma oferta pública de ações.

O terceiro investidor, com a concorrência oferecida pelo White Knight convocado pela administração da companhia fica desmotivado em realizar a tomada de controle da companhia-alvo (i) pela dificuldade em ter que negociar com os acionistas condições melhores que o White Knight e (ii) pela consequente necessidade de aumentar o preço de aquisição das ações de emissão da companhia-alvo.

O perigo à governança corporativa e aos acionistas que a prática do White Knight oferece, é que em casos que a administração da companhiaalvo convida um White Knight, e o mesmo aceita as condições da compra, as partes podem estabelecer um acordo para que a administração da companhia permaneça a mesma.

Essa prática é condenável uma vez que a administração da companhia deve se atentar ao exercício do objeto social da companhia com 
a maximização dos lucros e não ter seu lugar garantido em razão de prévio acordo.

O White Knight é uma forma de medida defensiva à tomada de controle hostil que pode ser implementada no Brasil. A CVM, inclusive, por meio da Instrução n. 361 de 5 de março de 2002 regula a prática de ofertas de ações concorrentes, estabelecendo, no seu artigo 12, parágrafo $5^{\text {o29 }}$ que a oferta concorrente deve ser feita com um preço no mínimo $5 \%$ superior à oferta pública oferecida pelo outro ofertante.

Neste sentido, para os acionistas não envolvidos na disputa societária ou ligados ao bloco de controle a prática do White Knight é geralmente benéfica, uma vez que aumenta o valor que será ofertado pelas ações detidas pelos acionistas.

\subsubsection{WHITE SQUIRE - ESCUDEIRO BRANCO}

O mecanismo de defesa do White Squire tem certa semelhança com o White Knight e tem, assim como os demais mecanismos de defesa, o objetivo de deixar a tomada de controle por um terceiro mais onerosa e com complicações operacionais.

Na defesa do White Squire - traduzido como Escudeiro Branco - um terceiro, escolhido pelos acionistas ou pela administração da companhia como um investidor estratégico, subscreve e integraliza uma quantidade significativa de ações em uma companhia que está passando por uma oferta hostil.

Em decorrência dessa subscrição e do pagamento das ações, o custo para que a tomada de controle aumenta significantemente, uma vez que,

\footnotetext{
29 Art. 12. A OPA será efetivada em leilão na bolsa de valores ou no mercado de balcão organizado em que as ações objeto da OPA sejam admitidas à negociação.

§50 Exclusivamente quando se tratar de OPA com preço à vista, a primeira interferência compradora deverá ser pelo menos $5 \%$ (cinco por cento) superior ao último preço oferecido.
} 
com a emissão de novas ações, é necessário comprar mais ações no mercado para que a tomada de controle seja bem sucedida.

Este mecanismo se mostra eficiente, mas tem diversas dificuldades para ser implementado em companhias, em razão de seu alto custo e em razão de complicações operacionais.

Primeiramente, a administração da companhia precisa encontrar um investidor estratégico interessado em realizar grandes aportes de capital, mas que não está interessado em tomar o controle da companhia. O investidor precisa estar ciente que o aumento do capital será puramente para afastar o terceiro adquirente e não para tomar o controle, uma vez que o investidor estratégico terá que aumentar o capital da companhia em um valor que não altere a estrutura de controle da companhia.

O mecanismo de defesa do White Squire, inclusive, é bastante comum entre investidores estratégicos que veem o White Squire como uma possibilidade de investimento em companhias por um preço um pouco inferior ao praticado no mercado.

Plínio José Lopes Shiguematsu aborda o tema mostrando como famosos investidores, como Warren Buffet, por meio de sua companhia Berkshire Hathaway, utiliza o White Squire como uma oportunidade de investimento:

Ele conseguiu participações em diversas companhias, através de sua empresa, a Berkshire Hathaway, ao participar como white squire em empresas como Gillette, Coca-Cola, U.S. Air e Salomon Brothers. Em 1989, ele investiu US\$ 600 milhões em ações preferenciais da Gillette, que, após a conversão lhe renderam uma participação de $11 \%$ nas ações com direito a voto. ${ }^{30}$

\footnotetext{
${ }^{30}$ SHIGUEMATSU, Plínio José Lopes. Mecanismos de proteção e estratégias de defesa em tomadas hostis de controle In: CASTRO, Rodrigo R. Monteiro de; ARAGÃO, Leandro Santos de. (Coord.). Direito Societário. Desafios atuais. São Paulo: Quartier Latin, 2009, p. 430.
} 


\subsubsection{CROWN JEWEL - JOIA DA COROA}

O White Knight, investidor alinhado com alguns acionistas e administração da companhia, pode também ser usado na forma de defesa como o detentor da Crown Jewel, as Joias da Coroa.

A defesa na forma do Crown Jewel consiste na prática de outorgar opção de compras a terceiros, usualmente White Knights, com o objetivo de dar a esses terceiros, opções de compras de ativos importantes da Companhia por preços abaixo dos praticados no mercado. Estes ativos ficaram conhecidos como as Joias da Coroa, ou as Crown Jewels.

Com a opção de compra sendo exercível após um período, sob uma certa condição ou a qualquer tempo, a companhia se torna menos atrativa para os avanços de um terceiro que deseja tomar o controle de tal companhia.

O terceiro interessado, visando tomar controle e extrair o máximo da produção de certos ativos, ficará muito menos tentado a investir na companhia ao ter conhecimento que importantes ativos da companhia desejada estão com uma opção de compra outorgada sobre eles.

O terceiro investidor, ao perceber que há uma opção de compra sobre os ativos terá que avaliar se o investimento em participação no capital social da companhia valerá a pena caso as opções de compra forem exercidas e as Joias da Coroa da companhia forem transferidas para terceiros.

A prática da modalidade de defesa do Crown Jewel, no entanto, sofre ainda muita resistência na doutrina e legislação brasileira. Isso ocorre, pois a Lei 6.404/76 veda o favorecimento específico de outra pessoa ou sociedade em prejuízo dos acionistas minoritários. 
Neste sentido o artigo 117, parágrafo 1, alínea (a) ${ }^{31}$ da Lei 6.404/76 responsabiliza o acionista controlador por atos que divergem do objeto social e que possam lesar a companhia em favorecimentos à outras sociedades.

A alienação de ativos da companhia para outras sociedades alinhadas com a administração da companhia pode ser considerada uma forma de lesão à companhia em desrespeito aos acionistas minoritários. Com a alienação dos ativos a potência de geração de lucros para a companhia decai e consequentemente o valor de ação e a geração de dividendos aos acionistas minoritários pode sofrer uma significante diminuição.

Neste momento é necessário ponderar se a outorga de opção de compra ao White Knight é mais benéfica aos acionistas da companhia do que o ingresso de um acionista que deseja realizar uma tomada hostil de controle na companhia.

Esta análise é bastante controversa e complicada de realizar uma vez que dificilmente a administração da companhia conseguiria quantificar o quanto lesivo à companhia será o ingresso do novo acionista enquanto, por motivos óbvios, é muito mais fácil concluir que a alienação de ativos para sociedades parceiras seria lesiva à companhia.

\subsubsection{GREENMAIL -CHANTAGEM SOCIETÁRIA}

O mecanismo de defesa Greemail é um mecanismo que pode se assemelhar à uma "chantagem societária". No mecanismo Greenmail, a administração da companhia ou seus acionistas adquirem do potencial investidor interessado em tomar o controle da sociedade as ações detidas

\footnotetext{
31 Art. 117. O acionista controlador responde pelos danos causados por atos praticados com abuso de poder.

$\S 1^{\circ}$ São modalidades de exercício abusivo de poder:

a) orientar a companhia para fim estranho ao objeto social ou lesivo ao interesse nacional, ou levála a favorecer outra sociedade, brasileira ou estrangeira, em prejuízo da participação dos acionistas minoritários nos lucros ou no acervo da companhia, ou da economia nacional;
} 
por ele na companhia-alvo, pagando um prêmio sobre as ações. Este mecanismo pode ser considerado uma "chantagem societária" uma vez que a administração ou os acionistas da companhia precisam ceder às pressões do terceiro adquirente e recomprar as ações detidas por tal acionista.

O Greenmail, no entanto, já teve sua validade questionada nos Estados Unidos e tem sua aplicabilidade questionada no Brasil. Ocorre que no Greenmail, a companhia, para oferecer prêmios para a compra, tem que escolher acionistas específicos para comprar suas ações e deixá-las em tesouraria.

No Greenmail, a companhia é obrigada a comprar ações de um acionista específico e por um preço superior ao preço praticado no mercado, e desta forma, pode caracterizar que a companhia está violando os princípios do artigo $30^{32}$ da Lei 6.404/76 que cria certas restrições à negociação das ações de emissão de uma companhia, pela própria companhia.

A Instrução 567 da CVM de 17 de setembro de 2015 estabelece certos critérios para a negociação das ações de companhias e, desta forma, a compra significante de ações para deixá-las em tesouraria pode cair em uma dessas punições, inviabilizando a técnica do Greenmail.

\footnotetext{
32 Art. 30. A companhia não poderá negociar com as próprias ações.

$\S 1^{\circ}$ Nessa proibição não se compreendem:

a) as operações de resgate, reembolso ou amortização previstas em lei;

b) a aquisição, para permanência em tesouraria ou cancelamento, desde que até o valor do saldo de lucros ou reservas, exceto a legal, e sem diminuição do capital social, ou por doação;

c) a alienação das ações adquiridas nos termos da alínea $b$ e mantidas em tesouraria;

d) a compra quando, resolvida a redução do capital mediante restituição, em dinheiro, de parte do valor das ações, o preço destas em bolsa for inferior ou igual à importância que deve ser restituída. $\S 2^{\circ} \mathrm{A}$ aquisição das próprias ações pela companhia aberta obedecerá, sob pena de nulidade, às normas expedidas pela Comissão de Valores Mobiliários, que poderá subordiná-la à prévia autorização em cada caso.

$\S 3^{\circ} \mathrm{A}$ companhia não poderá receber em garantia as próprias ações, salvo para assegurar a gestão dos seus administradores.

$\S 4^{\circ}$ As ações adquiridas nos termos da alínea $b$ do $\S 1^{\circ}$, enquanto mantidas em tesouraria, não terão direito a dividendo nem a voto.

$\S 5^{\circ}$ No caso da alínea d do $\S 1^{\circ}$, as ações adquiridas serão retiradas definitivamente de circulação.
} 
Nos Estados Unidos o Greenmail também já foi questionado com relação ao tratamento discriminatório que a companhia dá aos seus acionistas. Plínio Jose Lopes Shiguematsu descreveu em sua obra as críticas que a doutrina, jurisprudência e legislação norte-americana atribuíram ao Greenmail:

\begin{abstract}
Nos Estados Unidos, o seu uso foi questionado em algumas cortes e, embora possua uma natureza discriminatória, recebeu sinal verde da corte de Delaware, reconhecida por sua especialização em questões societárias. No entanto, a jurisprudência de cortes de outros estados norte-americanos, como a Califórnia, deram suporte aos acionistas que questionaram o uso do greenmail, por entender que ocorreu quebra do dever fiduciário dos administradores.

$(\ldots)$

(...) o governo buscou controlar esse tipo de operação e, em 1987, o congresso norte-americano inseriu em seu código de imposto sobre a renda a previsão de pagamento de uma alíquota de 50\% sobre o ganho realizado no recebimento de valores relacionados ao greenmail. ${ }^{33}$
\end{abstract}

\title{
3.5.5. PAC MAN DEFENSE- CONTRA ATAQUE
}

O mecanismo de defesa do Pac Man é um mecanismo distinto de todos os demais e de alta complexidade e custo para ser realizado. $\mathrm{Na}$ defesa de controle denominada Pac Man, a companhia que está em curso um de uma possível tomada de controle de forma hostil, contra-ataca e adquire o controle de própria companhia que está tentando tomar seu controle.

Neste sentido a própria companhia alvo, ou seus acionistas, ao adquirirem o controle da companhia que está tentando adquirir o controle da companhia alvo pode desistir da oferta pública e encerrar a tentativa de tomada hostil.

\footnotetext{
${ }^{33}$ SHIGUEMATSU, In: CASTRO; ARAGÃO, 2009, p. 425.
} 
Este mecanismo de defesa tem inúmeras dificuldades operacionais e financeiras. Primeiramente, caso a companhia que esteja tentando efetuar a tomada hostil de controle seja uma sociedade limitada ou uma sociedade anônima fechada e com poucos acionistas, a estratégia de contra-atacar e adquirir o controle da referida sociedade seria inócua, uma vez que os acionistas ou quotistas podem simplesmente se recusar a vender suas ações. A aquisição do controle só funcionária em companhias abertas com um free float grande que permitisse a troca de controle por compras particulares ou públicas.

Além das dificuldades operacionais, existem ainda as vastas dificuldades financeiras. São pouquíssimas as sociedades que detém dinheiro em caixa para adquirir uma companhia no meio de uma tentativa de tomada hostil de controle. As companhias que tentam tomar o controle de uma outra companhia geralmente são companhias valiosas com alto poder financeiro, e consequentemente, adquirir seu controle requer vultosos desembolsos.

Como a Pac Man Defense nada mais é que a oferta de compra de participação relevante ou do controle de uma companhia, sua validez é amparada pela legislação brasileira, mas com suas dificuldades operacionais e financeiras, tem sua aplicabilidade restringida no Brasil.

\subsection{OPA POR AQUISIÇÃO RELEVANTE DE PARTICIPAÇÃO - AS POISON PILLS BRASILEIRAS}

A cláusula estatutária de proteção à dispersão acionária é a modalidade de defesa às tomadas de controle mais usada no cenário empresarial brasileiro. Esse mecanismo de defesa é recorrentemente classificado como Poison Pill, no entanto conforme explicado anteriormente, a Poison Pill é uma forma diferente das cláusulas 
estatutárias de obrigatoriedade de realizar uma OPA em caso de aquisição relevante de participação.

O mercado em geral e diversos estudos jurídicos denominam a cláusula estatutária que obriga um acionista à realizar uma OPA em razão de aquisição relevante de participação como Poison Pill, mas, como tem significativas diferenças com a Poison Pill norte-americana e para facilitar a compreensão, serão denominadas de Poison Pill Brasileiras neste estudo.

Francisco Mussnich e Vitor de Britto Lobão Melo ${ }^{34}$, inclusive, apelidam esse mecanismo de Brazilian Pills, fazendo referências às grandes diferenças entre o mecanismo norte americano e o mecanismo brasileiro.

As denominadas Poison Pills Brasileiras se baseiam na ideia simples para evitar uma tomada de controle da companhia: na ideia de que a onerosidade excessiva da operação irá desmotivar um possível interessado em realizar a troca de controle.

As Poison Pills Brasileiras consistem na deliberação pela assembleia geral da companhia em inserir em seu estatuto uma cláusula que obriga qualquer acionista que adquira participação relevante na companhia à realizar uma Oferta Pública de Ações para a aquisição das demais ações do capital social da companhia.

Essa obrigação tem a intenção de deixar a tomada de controle da companhia excessivamente onerosa, uma vez que o investidor que desejar tomar o controle da companhia terá que adquirir a totalidade do capital social da companhia, que na grande maioria das companhias abertas consistiria no desembolso de centenas de milhões ou bilhões de reais.

A denominada "participação relevante" nas companhias depende do percentual estabelecido no estatuto social de cada companhia e o quanto seus acionistas desejam manter o capital pulverizado. Em companhias com

\footnotetext{
${ }^{34}$ ANTUNES MACIEL MUSSNICH, Francisco e BRITTO LOBÃO MELLO, Vitor, 254
} 
o capital extremamente pulverizado esta cláusula pode definir como participação relevante na companhia números como 10 a 20 por cento do capital votante da companhia.

Em companhias com o capital menos pulverizado, em que exista um bloco de controle, a porcentagem para que a participação relevante seja caracterizada pode chegar à até $40 \%$ do capital social.

Uma unanimidade entre as Poison Pills Brasileiras é que o gatilho para a realização da OPA, ou seja, a compra de participação significante, pode ser disparado mesmo quando a compra de participação relevante ocorrer com a compra de ações por diversos acionistas em separado.

Ocorre que se diversos acionistas do mesmo grupo econômico, ou até acionistas ligados por acordo ou sem acordo de voto, adquirirem separadamente participação relevante na companhia o gatilho para a realização da OPA para as demais ações da companhia ainda será acionado uma vez que a intenção desses acionistas é formar um bloco de controle ou, conjuntamente, ter influência significativa nas decisões sociais da companhia.

Uma crítica bastante pertinente que Francisco Mussnich e Vitor de Britto Lobão Melo fazem às Poison Pills Brasileiras é como em certos casos a má elaboração dessas cláusulas estatutárias podem abaixar a liquidez da companhia de uma forma que inviabilize o contínuo dos negócios da companhia. ${ }^{35}$

Isso pode ocorrer em casos que o preço para a realização da OPA fica estabelecido em um patamar excessivamente oneroso, inviabilizando qualquer forma de troca de controle. Nestes casos o controle da companhia poderá ficar engessado e consequentemente proteger somente o bloco de

3535 ANTUNES MACIEL MUSSNICH, Francisco e BRITTO LOBÃO MELLO, Vitor, 256 
controle, privilegiando a atual administração sem se atentar aos melhores interesses da companhia.

As Poison Pills Brasileiras, sofrem, ainda, críticas em virtude do engessamento do poder de controle da companhia. Como muitas das companhias que inserem o mecanismo da Poison Pill Brasileira em seus estatutos sociais são controladas na forma do controle majoritário a Poison Pill Brasileira pode ser usada puramente para manter o acionista controlador como detentor do controle da companhia.

\subsection{AS CLÁUSULAS PÉTREAS}

As administrações das companhias e os acionistas que deliberam pela inserção de cláusulas que contém mecanismos de defesa das tomadas hostis e para a proteção da dispersão acionária em seus estatutos sociais, tentam estabelecer mecanismos de reforçar essa proteção para que assembleias posteriores não possam retirar os mecanismos de defesa das tomadas hostis e para a proteção da dispersão acionária dos respectivos estatutos sociais.

Neste sentido, os mecanismos de defesa de tomadas hostis e para a proteção da dispersão acionária ficaram conhecidos como "cláusulas pétreas" nos estatutos sociais, uma vez que diversas companhias acrescentaram em seus estatutos sociais, sanções aos acionistas que votassem pela remoção dos referidos mecanismos nos estatutos sociais das companhias que deliberarem para retirar as Poison Pills Brasileiras em vigor nos estatutos das companhias.

A validade das referidas "cláusulas pétreas" foi objeto de bastante discussão, uma vez que as referidas cláusulas tentavam burlar um dos princípios básicos do direito societário brasileiro, o princípio da soberania das decisões da assembleia geral, positivada em nosso ordenamento jurídico 
no artigo 121 da Lei $6.404 / 76^{36}$. Além disso, as "cláusulas pétreas" foram criticadas por engessar os estatutos sociais das companhias, impedindo as companhias de mudarem e modernizarem seus estatutos.

A discussão sobre a validade das "cláusulas pétreas" chegou ao nível regulamentar quando a CVM, por meio do Parecer de Orientação, n. ${ }^{o} 36$ de 23 de junho de 2009, divulgou o entendimento de que a "CVM não aplicará penalidades, em processos administrativos sancionadores, aos acionistas que, nos termos da legislação em vigor, votarem pela supressão ou alteração da cláusula de proteção à dispersão acionária, ainda que não realizem a oferta pública prevista na disposição acessória."

Em outras palavras a CVM decidiu que acionistas que eventualmente votarem pela exclusão ou alteração das cláusulas pétreas não poderiam sofrer sanção por parte da CVM, quando julgados em processos administrativos.

O Parecer de Orientação n. ${ }^{\circ} 36$ estabeleceu que a CVM não poderia julgar contrariamente acionistas que votarem pela supressão ou exclusão dos mecanismos de defesa das tomadas hostis e para a proteção da dispersão acionária pois seria uma violação dos artigos $115^{37}, 121,122^{38}$, I, e $129^{39}$ da Lei 6.404/76. Desta forma a CVM entendeu, resumidamente que a inserção de "cláusulas pétreas" nos estatutos sociais das companhias usurparia o poder da assembleia geral, que seria, mesmo com quórum qualificado, impedida de alterar o ou excluir os mecanismos de defesa das tomadas hostis e para a proteção da dispersão acionária.

\footnotetext{
36 Art. 121. A assembléia-geral, convocada e instalada de acordo com a lei e o estatuto, tem poderes para decidir todos os negócios relativos ao objeto da companhia e tomar as resoluções que julgar convenientes à sua defesa e desenvolvimento.

37 Art. 115. O acionista deve exercer o direito a voto no interesse da companhia; considerar-se-á abusivo o voto exercido com o fim de causar dano à companhia ou a outros acionistas, ou de obter, para si ou para outrem, vantagem a que não faz jus e de que resulte, ou possa resultar, prejuízo para a companhia ou para outros acionistas.

${ }^{38}$ Art. 122. Compete privativamente à assembleia geral:

I - reformar o estatuto social;

39 Art. 129. As deliberações da assembléia-geral, ressalvadas as exceções previstas em lei, serão tomadas por maioria absoluta de votos, não se computando os votos em branco.
} 
Importante notar também que a atuação da CVM neste caso foi considerada discreta, uma vez que a CVM não usou o seu poder regulamentar e não proibiu as "cláusulas pétreas", mas somente especificou que não punirá quem votar contra.

As "cláusulas pétreas" também foram objeto de discussão no âmbito da regulamentação privada. Em 2009 a BM\&FBovespa em proposta para reformar o regulamento do Novo Mercado e do Nível 2 propôs inserir uma cláusula para proibir que companhias listadas no Novo Mercado e no Nível 2 da BM\&FBovespa tivessem em seus estatutos sociais cláusulas que criasse sanções para acionistas que votassem contra as Poison Pills Brasileiras.

Após consulta à advogados, companhias, ABRASCA (Associação Brasileira de Companhias Abertas) foi aprovada, nos termos da pauta votação da BM\&FBovespa, a "Vedação à cláusula que impeça o exercício de voto favorável ou imponha ônus aos acionistas - "cláusula pétrea"”, pela maioria dos participantes de cada segmento.

Essa decisão, junto com o Parecer de Orientação n. ${ }^{\circ} 36$ da CVM consolidou o entendimento de que a cláusulas pétreas nos estatutos sociais das companhias "não se compatibilizam com diversos princípios e normas da legislação societária em vigor" nos termos do Parecer de Orientação n. ${ }^{\circ}$ 36 da CVM. 


\section{CAPÍTULO 4 - COMPARAÇÕES E EXPERIÊNCIAS INTERNACIONAIS}

As medidas defensivas às tomadas de controle e seus mecanismos são usados de forma global e na vasta maioria de países com uma economia forte e uma legislação comercial avançada. O uso dessas medidas, no entanto, é mais frequente em alguns países que outros, com os Estados Unidos tendo, disparadamente, a maior experiência com os mecanismos de dispersão acionária e métodos de evitar a tomada de controle por investidores hostis.

As experiências na jurisprudência e nas legislações estrangeiras demonstram como certas medidas defensivas podem ser mais eficazes em alguns casos que em outros e, mais importante, como sua validade pode ser questionada pela legislação de alguns países.

A experiência norte-americana, por exemplo, mostra que as decisões dos tribunais especializados em conflitos empresariais majoritariamente indicam que o judiciário deve influenciar o mínimo possível nas decisões tomadas pela administração das companhias e pelas decisões deliberadas em assembleias gerais.

A Suprema Corte dos Estado de Delaware, decide questões relativas às medidas defensivas às tomadas de controle desde a década de $80 \mathrm{e}$ consequentemente é referência mundial em como lidar com situações em que se tem que ponderar as decisões tomadas pela administração e o direito positivado na legislação comercial.

A experiência norte-americana também demonstra que a possibilidade de uso de mecanismos de defesa às tomadas hostis e os mecanismos para se preservar a dispersão acionária são inúmeros, uma vez 
que a administração de cada companhia pode estabelecer o mecanismo de defesa que melhor se adapta às suas condições.

O mecanismo do Crown Jewel, por exemplo, é um mecanismo que tem seu uso no cenário empresarial norte-americano, mas dificilmente seria usado no Brasil, uma vez que a outorga de opção de compra de importantes ativos da companhia poderia caracterizar o favorecimento ilegal à certos acionistas ou terceiros.

O mesmo pode ser dito com relação ao Greenmail, que tem sua legalidade questionada tanto no Brasil como nos Estados Unidos. No Brasil, com base no artigo 30 da Lei 6.404/76 dificilmente um tribunal judicial ou arbitral permitiria que a companhia comprasse uma quantidade significante de ações de um determinado acionista (e por um preço superior ao praticado no mercado) sem que os demais acionistas recebessem o mesmo tratamento.

\subsection{BUSINESS JUDGMENT RULE - REGRA DO JULGAMENTO COMERCIAL}

O Business Judgment Rule - que pode ser traduzido com a Regra do Julgamento Comercial - pode ser considerada a forma mais comum de argumentar a legalidade de um mecanismo de defesa de tomadas de controle e a doutrina brasileira em grande maioria apoia o seu uso para as companhias brasileiras.

O Business Judgment Rule consiste na ideia de que os atos internos das companhias e os atos da administração da companhia devem sofrer o mínimo de interferência do poder judiciário ou qualquer outra esfera além do âmbito da própria companhia. Neste sentido, o Business Judgment Rule é usado para que a administração da companhia possa exercer suas funções sem o constante receio de judicialização ou anulação seus atos. 
O Business Judgment Rule, consiste, ainda, na presunção de que os atos praticados pela administração da companhia se baseiam na boa fé e no entendimento de que a medida tomada pela administração visa o melhor interesse da companhia.

O professor da Harvard School of Law, Guhan Subramanian, ao explicar o caso Aronson v. Lewis, Del.Supr., 473 A.2d 805, 812 (1984), julgado pela Suprema Corte do Estado de Delaware explica o Business Judgment Rule da seguinte forma:

"The business judgment rule is 'a presumption that in making a business decision the directors of a corporation acted on an informed basis, in good faith and in the honest belief that the action taken was in the best interests of the company"'40

Neste sentido, o Business Judgment Rule é usado pelos acionistas e pela administração da companhia na defesa de diversas formas de cláusulas estatutárias e contratuais que dificultam a tomada de controle. A administração da companhia, pode, por exemplo, argumentar que com base no Business Judgment Rule, a Crown Jewel (conforme descrita acima) em que opção de compra de ativos da companhia é outorgada à terceiros ou à acionista da companhia deve ser considerada válida pelo Poder Judiciário, ou, ainda, que o Poder Judiciário não deve interferir no julgamento.

O Business Judgment Rule tem sua aplicabilidade de forma parcial no Brasil, uma vez que a atuação da administração da companhia não é ilimitada e deve seguir a legislação aplicável no que concerne aos seus atos praticados. O artigo 159, parágrafo $6,{ }^{41}$ da Lei $6.404 / 76$ estabelece que em ações judiciais o juiz ao decidir com relação à ações relacionadas à atos

40 O Business Judgment Rule como sendo uma presunção de que as decisões negociais dos diretores de companhias são tomadas com base em informações de qualidade, de boa-fé e no honesto entendimento de que a atitude realizada foi no melhor interesse da companhia. Tradução livre do original.

SUBRAMANIAN, Guhan. The Poison Pill. Harvard Business School Review, Cambridge, 9 Nov. 2001, p. 8.

41 159. Compete à companhia, mediante prévia deliberação da assembléia-geral, a ação de responsabilidade civil contra o administrador, pelos prejuízos causados ao seu patrimônio.

$\S 6^{\circ} \mathrm{O}$ juiz poderá reconhecer a exclusão da responsabilidade do administrador, se convencido de que este agiu de boa-fé e visando ao interesse da companhia. 
praticados pelos administradores da companhia deve levar em consideração a boa-fé visando o interesse da Companhia.

Desta forma, ao comprovar que a decisão da administração visou puramente resguardar os interesses da companhia, o administrador deve ter sua responsabilidade excluída e, consequentemente, a Business Judgment Rule deve ser aplicada.

Osmar Brina Corrêa-Lima faz uma ligação entre o Business Judgment Rule e o artigo 159, parágrafo 6, da Lei 6.404/76 ao explicar que:

\begin{abstract}
"O parágrafo 6 cuida de hipótese excludente de responsabilidade. Ou seja o juiz reconhece que o administrador agiu em violação dos seus deveres, mas exclui a o dever de indenizar por estar convencido de que o administrador agiu de boa-fé e visando ao interesse da companhia. Para a aplicação do preceito é indispensável a presença de ambos os requisitos, isto é o reconhecimento judicial de que o administrador agiu de boa-fé e visando o interesse da companhia. A ausência de qualquer desses requisitos impede a exclusão do dever de indenizar. Assim, atos dolosos não autorizam aplicação do parágrafo 6, uma vez que excluem a boa-fé exigida pela lei. Além disso, a aplicação do parágrafo 6, combinado com o disposto no artigo $944^{42}$, parágrafo único, do Código Civil em vigor, autoriza concluir que o juiz pode reduzir equitativamente o valor da indenização: afinal quem pode o mais (ou seja, eximir o administrador de responsabilidade) pode o menos (reduzir a condenação imposta). Por fim, poderia a assembleia geral, substituindo-se ao juiz da causa, isentar o administrador de responsabilidade perante a companhia por se convencer de que este agiu de boa fé e visando o interesse da companhia? Entendo que não, porquanto, em primeiro lugar a lei prevê o perdão judicial, não atribundo poderes de exoneração de responsabilidade à assembleia geral; em segundo lugar; porque, conforme o disposto no artigo 109, parágrafo $2^{43}$, "os meios, processos ou ações que a lei confere aos acionista para assegurar seus direitos não podem ser elididos pelo estatuto ou pela assembleia geral"44.
\end{abstract}

Desta forma, percebe-se que o Business Judgment Rule no Brasil tem uma atuação um pouco menos abrangente do que na esfera norte-americana. Na esfera norte-americana o Business Judgment Rule detém uma ideia de que as decisões tomadas pela administração da companhia devem ter a

\footnotetext{
42 Art. 944. A indenização mede-se pela extensão do dano.

Parágrafo único. Se houver excessiva desproporção entre a gravidade da culpa e o dano, poderá o juiz reduzir, equitativamente, a indenização.

$43 \S 2^{\circ}$ Os meios, processos ou ações que a lei confere ao acionista para assegurar os seus direitos não podem ser elididos pelo estatuto ou pela assembléia-geral.

${ }^{44}$ LAZZARESCHI NETO, Alfredo Sérgio. Lei das Sociedades por Ações Anotada. p. 159.
} 
presunção de boa decisão ou julgamento do negócio e estas decisões estão afetadas se não tomadas de forma diligente e racional.

Os pilares que sustentam a ideia do Business Judgment Rule nos Estados Unidos são quatro: (i) primeiramente, os tribunais norte-americanos trabalham com a ideia de que os administradores podem render às companhias grandes lucros, logo, atos praticados em certos momentos, podem render lucros aos acionistas após um longo período depois. Desta forma, o Business Judgment Rule premia os administradores competentes que trabalham com a ideia de lucros a longo prazo; (ii) o Business Judgment Rule reconhece que os administradores em busca de aumentar as receitas de sua companhia administrada, tomam riscos e entram em campos de incertezas comerciais, e consequentemente, premia os administradores que saem de sua área de conforto e visam maiores lucros às companhias, dandolhes mais conforto para assumir tais riscos; e (iii) o Business Judgment Rule também tende a desestimular o Poder Judiciário de interferir em ações internas da companhia.

Com base do Business Judgment Rule existe uma presunção de que os administradores têm mais capacidade de administrar as sociedades do que juízes membros do Poder Judiciário, logo, suas decisões não devem ser substituídas por decisões judiciais.

Em geral, essa especificidade gera aos próprios acionistas da companhia uma segurança jurídica muito maior, ao saberem que as decisões tomadas pela administração não sofrerão mudanças pelo Poder Judiciário futuramente, e por fim, a regra do Business Judgment Rule protege os próprios acionistas dos demais acionistas. Afinal, se as decisões da administração da companhia forem transferidas para a assembleia geral, os 
acionistas que elegeram a administração terão seus votos praticamente descartados. ${ }^{45}$

O Business Judgment Rule norte-americano - e que norteia o Business Judgment Rule de forma global - define que para que seja legalmente estabelecido uma relação de Business Judgment Rule nos atos dos administradores, são necessários cinco elementos essenciais.

Primeiramente somente as decisões tomadas pelos administradores da companhia podem ser protegidas pelo Business Judgment Rule. Em seguida deve ser levado em consideração de que as decisões precisam ser tomadas com desinteresse e independência.

Nos termos da legislação norte americana (mais precisamente da lei comercial do Estado do Texas) o desinteressado é o administrador ou pessoa a ele ligado por relação financeira, familiar de negócio ou qualquer pessoa que não tem interesse financeiro ou material na transação.

O Revised Model Business Corporation Act (RMBCA), guia publicado pela American Bar Association (equivalente, nos Estados Unidos, ao Conselho Federal da Ordem do Advogados do Brasil) explica em sua seção $8.31^{46}$ situações que mitigam a responsabilidade dos

\footnotetext{
${ }^{45}$ BLOK, Marcella. Revista de Direito Bancário e Mercado de Capitais. 46. dez 2009, p. 129.

${ }^{46}$ A director shall not be liable to the corporation or its shareholders for any decision to take or not to take action, or any failure to take any action, as a director, unless the party asserting liability in a proceeding establishes that: (1) no defense interposed by the director based on (i) any provision in the articles of incorporation authorized by section 2.02(b)(4) or, (ii) the protection afforded by section 8.61 (for action taken in compliance with section 8.62 or section 8.63 ), or (iii) the protection afforded by section 8.70 , precludes liability; and (1) the challenged conduct consisted or was the result of: (i) action not in good faith; or (ii) a decision (A) which the director did not reasonably believe to be in the best interests of the corporation, or (B) as to which the director was not informed to an extent the director reasonably believed appropriate in the circumstances; or a lack of objectivity due to the director's familial, financial or business relationship with, or a lack of independence due to the director's domination or control by, another person having a material interest in the challenged conduct which relationship or which domination or control could reasonably be expected to have affected the director's judgment respecting the challenged conduct in a manner adverse to the corporation, andafter a reasonable expectation to such effect has been established, the director shall not have established that the challenged conduct was reasonably believed by the director to be in the best interests of the corporation; or a sustained failure of the director to devote attention to ongoing oversight of the business and affairs of the corporation, or a failure to devote timely attention, by making (or causing to be made) appropriate inquiry, when particular facts and circumstances of significant concern materialize that would alert a reasonably
} 
administradores por quebra no dever de diligência. Resumidamente, o Revised Model Business Corporation Act estabelece que (a) ocorrência de atos de boa-fé, (b) atos que atentam ao interesse da companhia, (c) com informações suficientes para a tomada de decisão e (d) não existência de benefício pessoal ${ }^{47}$ podem ser consideradas como Business Judgment Rule, e consequentemente mitigar ou excluir a responsabilidade do administrador.

\subsection{POSIÇÃO DO JUDICIÁRIO NORTE AMERICANO COM RELAÇÃO AO POISON PILL E DEMAIS MECANISMOS DE DEFESA}

A Poison Pill e os demais mecanismos de defesa contra mudança de controle de companhias já foram questionados inúmeras vezes, especialmente no âmbito da Suprema Corte do Estado de Delaware. A legislação societária do Estado de Delaware é considerada como a mais avançada dos Estados Unidos e o polo das mais acirradas disputas comerciais entre companhias e entre seus acionistas e administradores.

A Suprema Corte do Estado de Delaware já foi provocada inúmeras vezes para debater a legalidade da Poison Pill e suas diversas formas, e, atualmente, possui uma jurisprudência consolidada de que a análise deve ser feita de caso a caso, como cada mecanismo de defesa tem suas peculiaridades.

A Suprema Corte do Estado de Delaware, seguindo a forte tendência norte-americana de pouca intervenção estatal ou judiciária nas atividades empresariais, leva o Business Judgment Rule em consideração de cada caso, fazendo uma ponderação entre o Business Judgment Rule exercido pela administração e os direitos do investidor interessado em assumir o controle da companhia.

attentive director to the need therefore; or receipt of a financial benefit to which the director was not entitled or any other breach of the director's duties to deal fairly with the corporation and its shareholders that is actionable under applicable law.

${ }^{47}$ BLOK, 2009, p. 129. 
A Poison Pill Norte-Americana teve sua legalidade confirmada pelos tribunais norte-americanos em 1985, no leading case de Moran $v$. Household International, Inc.

Este caso específico, que abriu as portas para que demais companhias pudessem inserir em seus estatutos cláusulas de Poison Pill com segurança de que tal dispositivo não seria mais questionado, envolveu a Household International, Inc. e a composição do Conselho de Administração. O Conselho de Administração da Household International, Inc. era composto por dezesseis membros eleitos pelos diversos acionistas da companhia. Em Reunião do Conselho de Administração da Household International, Inc. os membros do Conselho de Administração da Household International, Inc. aprovaram, por 14 a 2, a inserção de uma cláusula de Poison Pill em seu estatuto para prevenir potenciais mudanças de controle.

A Poison Pill proposta pelo Conselho de Administração consistia em Poison Pill da modalidade de Flip-Over. A aprovação da Poison Pill não agradou Dyson-Kissner-Moran Corporation, que na época era a maior acionista da companhia, mesmo não possuindo o controle da companhia, pois inviabilizaria qualquer possibilidade de uma possível mudança de controle, em razão de excessiva onerosidade.

O membro do Conselho de Administração dissidente da votação da Reunião do Conselho de Administração, representante da Dyson-KissnerMoran Corporation na companhia, protestou alegando que a cláusula de Poison Pill não era válida, uma vez que não estava em curso qualquer tentativa de oferta hostil contra a Household International, Inc.

Quando o caso chegou à Suprema Corte do Estado de Delaware o tribunal analisou o caso a luz do Business Judgment Rule. O tribunal decidiu que a inserção de cláusula de Poison Pill, mesmo de modo preventivo, era puramente discricionário pelo Conselho de Administração, e 
que não cabia ao judiciário intervir nas decisões tomadas pelo Conselho de Administração da Companhia.

A Suprema Corte do Estado de Delaware, inclusive, decidiu que a adoção de uma Poison Pill de forma preventiva era legítima, uma vez que tinha como função proteger os acionistas da companhia de uma eventual mudança de controle realizada por uma oferta hostil.

\subsection{ANÁLISE COMPARATIVA ENTRE O DIREITO ESTRANGEIRO E O DIREITO BRASILEIRO COM RELAÇÃO ÀS MEDIDAS DEFENSIVAS DE TOMADA DE CONTROLE}

Após a análise entre as medidas defensivas para as tomadas hostis de controle, é possível avaliar que o direito estrangeiro e o direito brasileiro possuem grandes diferenças em diversas esferas, principalmente atribuídas ao cenário econômico de cada região.

Primeiramente, existe o fator jurídico, i.e. como a legislação de cada país interfere na possibilidade de usar cada medida defensiva. Neste sentido, conforme explicado acima, uma série de mecanismos de defesa às tomadas hostis e formas de preservar a dispersão acionária são usadas por companhias norte-americanas e que não poderiam ser usadas no âmbito societário brasileiro.

Analisamos, que, por exemplo o mecanismo do Greenmail dificilmente poderia ser usado por companhias brasileiras, resumidamente em razão da vedação estabelecida pelo artigo 30 da Lei 6.404/76 e da Instrução 567 da CVM de 17 de setembro de 2015.

O Sttagered Board é outro mecanismo de defesa às tomadas hostis que demonstra as grandes diferenças entre a legislação de cada país. Analisamos que o Staggered Board não seria aplicável à companhias em 
razão do direito de destituição a qualquer momento pela maioria do capital social das companhias brasileiras

Outra restrição que merece atenção para verificar as diferenças é a grande diferença entre o cenário econômico e como as sociedades anônimas são estruturadas em cada país. O cenário brasileiro, conforme descrito acima, têm a maioria das companhias controladas na forma do controle majoritário. Desta forma, são raros os casos em que um bloco de controle, uma família, ou um acionista não tenha a maioria das ações ou uma quantidade suficiente de ações que o permita controlar a companhia.

Conforme já explicado, a forma majoritariamente de controle estabelecido como o controle majoritário vem em razão do pouco desenvolvimento do mercado de capitais e da cultura do controle majoritário, em que poucos grupos empresariais ainda detém a maioria do capital social. Desta forma alguns mecanismos de defesa são incompatíveis com a realidade brasileira uma vez que não seriam possíveis de defender os interesses minoritários nas companhias.

Diante do cenário de forte presença do controle majoritário nas companhias brasileiras, a Poison Pill Brasileira torna-se disparada a técnica mais usada por sociedades brasileiras, que, comparativamente, poderia não ter a mesma efetividade com companhias de outros países.

A Poison Pill Brasileira pode se adequar ao cenário brasileiro e encaixar nos estatutos sociais das companhias, pois, em diversos casos foi fundamental para manter o próprio bloco de controle no controle da companhia no comando, evitando que uma sociedade que está sob controle de um grupo de acionistas ou uma família mude de controle para um terceiro. 


\section{CONCLUSÃO}

A análise deste estudo comparativo da legislação brasileira e estrangeira, focado principalmente no direito norte-americano, traz reflexões à diversos pontos com relação à prática jurídica e comercial das defesas às tomadas de controle hostis e à proteção à dispersão acionária.

Primeiramente é necessário constar como a legislação a prática jurídica norte-americana está vários passos a frente da prática brasileira. Um conjunto de fatores históricos e comerciais fizeram com que a legislação norte-americana e o entendimento dos tribunais norte-americanos avançassem a passos largos para conseguir acompanhar o ritmo do desenvolvimento empresarial.

Conforme demonstrado, pela evolução histórica e pela atual conjuntura do cenário empresarial brasileiro, a forma de poder de controle altamente concentrado no controle majoritário ou mesmo no controle totalitário traz inúmeras dificuldades para a evolução da matéria relativa à proteção à dispersão acionária no Brasil.

O cenário brasileiro, diferentemente do cenário empresarial norteamericano ainda é muito tímido com relação às demais formas de controle, sendo o controle gerencial, por exemplo, ainda inexistente no Brasil.

No entanto, verificou-se por meio da doutrina e da jurisprudência que o poder de controle na forma minoritária e gerencial tem sua legalidade reconhecida no Brasil e que existem companhias se esforçando para pulverizar o seu capital social e espalha-lo perante diferentes acionistas, privilegiando a governança corporativa das companhias.

Além disso, em comparação aos mecanismos de defesa às tomadas de controle e medidas possíveis para incentivar a pulverização do controle em sociedades anônimas há de se ressaltar diversos pontos. Primeiramente, 
observamos que os mecanismos de defesa às tomadas de controle tem sua atuação muito presente nos Estados Unidos, principalmente com a adoção do privilégio às decisões tomadas pela administração da companhia e a interferência mínima pelo poder judiciário, com respaldo no princípio do Business Judgment Rule.

O Business Judgment Rule autoriza a administração das companhias a tomar atitudes ousadas, que na visão da administração da companhia, tendem a valorizar o valor das ações de emissão da companhia.

O Business Judgment Rule deve sempre ser ponderado com os direitos positivados na legislação e, consequentemente, tanto no Brasil como em outras legislações, tem sua efetividade reduzida em algumas ocasiões. Pode se verificar, por exemplo, que mecanismos de defesa como o Crown Jewel não seriam facilmente utilizados no Brasil com respaldo no Business Judgment Rule, uma vez que a nossa legislação e jurisprudência vedam o esvaziamento de patrimônio e a tomada de atitudes que beneficiem certos acionistas ou investidores.

Os mecanismos de defesa às tomadas hostis tiveram sua legalidade confirmada pelos tribunais norte-americanos, mais precisamente os tribunais do estado de Delaware, e, consequentemente, consagraram o princípio do Business Judgment Rule e da validade de mecanismos para proteger a companhia de uma eventual mudança de controle e de defesa da pulverização do capital social da companhia.

Ademais, verificamos a grande diferença entre as Poison Pills Brasileiras e as Poison Pills norte-americana. As Poison Pills Brasileiras têm, em regra, como princípio, a obrigatoriedade de realização de Oferta Pública de Aquisição de Ações quando um acionista atingir determinada porcentagem de participação social na companhia. A Poison Pill NorteAmericana, por outro lado, visa criar direitos aos acionistas da companhia para dificultar a mudança de controle de companhia. 
No entanto, todas as medidas defensivas, inclusive a Poison Pill Brasileira e a Poison Pill tem como objetivo restringir a mudança de controle em uma companhia, ou evitar que acionistas adquiram participação relevante na companhia, tornando a possível aquisição de controle ou de participação relevante extremamente complicada, burocrática e onerosa ao terceiro adquirente.

A Poison Pill Brasileira foi introduzida nos estatutos sociais de inúmeras companhias e teve sua efetividade comprovada diversas vezes, mostrando que sua introdução no cenário brasileiro pode ser benéfica para a melhoria do mercado de capitais do Brasil.

No entanto, conforme explicado anteriormente, as Poison Pills Brasileiras têm certas falhas, como a redução da liquidez e a possibilidade de diminuição da oferta de crédito. Com relação às Poison Pills Brasileiras, verificamos também que as denominadas "cláusulas pétreas" das Poison Pills Brasileiras tiveram sua validade questionada pela CVM, mas a própria CVM não estabeleceu consequências às companhias que inserirem "cláusulas pétreas" em seus estatutos sociais.

Para se analisar a Poison Pill Brasileira é necessário o devido estudo do cenário empresarial brasileiro, em que a vasta maioria das sociedades anônimas no Brasil ainda são detidas por um grupo de controle que não deseja perder o controle da companhia para terceiros adquirentes diferentemente das companhias norte-americanas, onde a pulverização do capital social prevalece.

Por fim, há de se concluir que as medidas defensivas às tomadas hostis e os mecanismos que protegem a dispersão acionário no Brasil ainda contém muitas falhas e andam em pequenos passos com relação ao cenário internacional. 
No entanto, é louvável a intenção de algumas companhias em inserir em seus estatutos e demais documentos corporativos mecanismos que privilegiam as boas práticas com relação à governança corporativa, proteção aos minoritários e melhor interesse da companhia. 


\section{REFERÊNCIAS BIBLIOGRÁFICAS}

ANTUNES MACIEL MUSSNICH, Francisco e BRITTO LOBÃO MELLO, Vitor. Análise Prática e Considerações sobre a Realidade e a Aplicação das Medidas de Proteção à Tomada Hostil de Controle nos Estatutos Sociais das Companhias Abertas Brasileiras ("Poison Pills"). In: COUTO SILVA, Alexandre (Org.) Direito Societário Estudos sobre a Lei de Sociedades por Ações. São Paulo. Ed Saraiva.

BARROSO DO NASCIMENTO, João Pedro. Medidas Defensivas à Tomada de Controle de Companhias. São Paulo. ed. Quartier Latin, 2011.

BLOK, Marcella. Revista de Direito Bancário e Mercado de Capitais $n .^{\circ}$ 46. WALD, Arnoldo (Cord.)São Paulo. Ed. Revista dos Tribunais. dez 2009.

BORBA, José Edwaldo Tavares. Direito Societário. São Paulo. $14^{\mathrm{a}}$ ed Atlas, 2015.

CARVALHOSA, Modesto. Comentários à Lei das Sociedades Anônimas. vol. $4^{\circ}$. São Paulo. ed Saraiva. 2014

COELHO, Fábio Ulhoa. Curso de direito comercial. São Paulo: ed. Saraiva, 1999.

COLEGIADO CVM. Proc2001/10329, Reg. 3528/02, Rel. Diretor Marcelo Trindade, j. 19.2.2002.

COMPARATO, Fábio Konder. Direito empresarial. São Paulo: ed. Saraiva, 1995.

EIZIRIK, Nelson. Aquisição de Controle. Inexigibilidade de Oferta Pública. In CASTRO, Rodrigo R. Monteiro de; ARAGÃO, Leandro Santos de. (Coord.). Direito Societário. Desafios atuais. São Paulo: Quartier Latin, 2009.

LAMY FILHO, Alfredo; BULHÕES PEDREIRA, José Luiz. A Lei das S.A.: pressupostos, elaboração, aplicação. Rio de Janeiro: Renovar, 1992.

LAZZARESCHI NETO, Alfredo Sérgio. Lei das Sociedades por Ações Anotada. São Paulo. Ed: Saraiva. 2012 
LIPTON, Martin; ROWE, Paul K. Pills. Polls and professors: a reply to professor Gilson. New York: New York University Center for Law and Business, Apr. 2001, p. 13. Disponível em:

$<$ http://papers.ssrn.com/paper.taf?abstract_id=268520〉. Acesso em: 22 mai. 2016.

LUCENA, José Waldecy. Das sociedades anônimas. Comentários à lei (artigos $1^{\circ}$ a 120). v. 1. Rio de Janeiro: Renovar, 2009.

MARTINS NETO, Carlos. Dispersão Acionária, Tomada Hostil de Controle e Poison Pills: Breves Reflexões, Disponível em: <http://www.bocater.com.br/UPLOAD/noticias/564d93f37f654.pdf> Acesso em 25 de fevereiro de 2016.

OIOLI, Erik Frederico. Oferta Pública de Aquisição do Controle de Companhias Abertas. Coleção IDSA de Direito Societário e Mercado de Capitais, v. 1. São Paulo: Quartier Latin, 2010.

PONTES DE MIRANDA, Francisco Cavalcanti. Tratado de direito privado. t. L. Atualizado. São Paulo: Revista dos Tribunais, 2012.

REVISTA CAPITAL ABERTO. Anuário de Governança Corporativa das Companhias Aberta.

SHIGUEMATSU, Plínio José Lopes. Mecanismos de proteção $e$ estratégias de defesa em tomadas hostis de controle In: CASTRO, Rodrigo R. Monteiro de; ARAGÃO, Leandro Santos de. (Coord.). Direito Societário. Desafios atuais. São Paulo: Quartier Latin, 2009.

SUBRAMANIAN, Guhan. The Poison Pill. Harvard Business School Review, Cambridge, 9 Nov. 2001. 